\title{
BIM-LCA Integration for the Environmental Impact Assessment of the Urbanization Process
}

\author{
Madelyn Marrero ${ }^{1, *(\mathbb{D}}$, Maciej Wojtasiewicz ${ }^{2}$, Alejandro Martínez-Rocamora ${ }^{1}{ }^{1}$, \\ Jaime Solís-Guzmán ${ }^{1}$ and M. Desirée Alba-Rodríguez ${ }^{1}$ (1) \\ 1 ArDiTec Research Group, Department of Architectural Constructions II, Higher Technical School of Building \\ Engineering, Universidad de Sevilla, 41012 Seville, Spain; rocamora@us.es (A.M.-R.); \\ jaimesolis@us.es (J.S.-G.); malba2@us.es (M.D.A.-R.) \\ 2 Datacomp, 30-532 Kraków, Poland; m.wojtasiewicz@datacomp.com.pl \\ * Correspondence: madelyn@us.es; Tel.: +34-954-55-6661
}

Received: 29 April 2020; Accepted: 18 May 2020; Published: 20 May 2020

check for updates

\begin{abstract}
The construction sector is one of the most polluting industries, generating between 30\% and $40 \%$ of the worldwide environmental burden in terms of raw materials, direct and indirect energy consumption, waste, and $\mathrm{CO}_{2}$ emissions. Recent advances in computer science and data management have facilitated the evaluation of present and future impacts, thus improving the sustainability of architectural designs. Powerful software tools, such as Building Information Modelling (BIM), allow environmental indicators to be incorporated into the construction elements that make up the project to evaluate it during the design stage. In this work, the state of the art of ecological indicator application through BIM platforms is studied. Barriers and uncertainties are also identified. Subsequently, a model is proposed to evaluate the environmental impact of an urbanization process or a project through several ecological indicators (carbon footprint, water footprint, and embodied energy). To perform this analysis, the most important aspect is to determine the quantities of each construction element and their clear decomposition into subelements, since both aspects add certainty to the analysis. For this purpose, construction cost databases are a good instrument for introducing environmental awareness. The reliability of LCA data, which can be obtained from generic databases or ecolabels such as environmental product declarations, becomes crucial.
\end{abstract}

Keywords: life cycle assessment; building information modelling; environmental product declaration; ecolabels; environmental impact assessment; urbanization

\section{Introduction}

Buildings represent between $30 \%$ and $40 \%$ of worldwide environmental impact, whether directly by their use or indirectly as part of the embodied impact of the construction materials consumed. This encourages architects and engineers to design more sustainable buildings, which implies lower energy and resource consumption [1]. Several tools and calculation models to determine the environmental impact of the construction sector are in place, whether using single issue indicators, such as the embodied energy (EE) or carbon footprint (CF) [2], or more complex ones such as emergy [3,4], the ecological footprint (EF) [5-9], CML, or the eco-indicator, also known as multivariable indicators.

Methods putting together data from the entire construction process are being developed, but the inclusion of environmental concerns during the design stage represents one of the greatest challenges for designers. For this reason, the European Committee for Standardization promotes, in the production phase of buildings, the integration of environmental concerns by defining the European Guidelines on Sustainability in Construction Works [10]. In addition, the European Directive 2014/24/EU on public procurement states that, for public works contracts and design competitions, Member States should use 
specific electronic tools, such as electronic modelling tools, in construction. Spain, the United Kingdom, Germany, and France are transposing these guidelines into their government regulations [11-14]. However, there are important barriers to be overcome, such as accessibility to environmental data, high expertise requirements, and the difficult identification of alternative components or materials [15].

Building Information Modelling (BIM) is increasingly used to offer comprehensive project planning, design, and management, mainly for new buildings [16]. BIM software adds information to building projects, so the designer now draws constructive elements and simultaneously defines their characteristics or parameters in the current life cycle stage of the project [17]. This type of software allows additional information to be included in the construction elements, such as life cycle assessment (LCA) data, which can improve decision-making during the design stage [18-20]. This environmental impact assessment usually includes the consumption of construction materials and energy, greenhouse gas (GHG) emissions, and construction and demolition waste (CDW) generation [21].

However, BIM software should meet more requirements for building designers [22]. One of the main barriers that designers face is working with different software, databases, and methodologies [23]. LCA integration with BIM requires programming skills, so the assessment is a multidisciplinary task in which environmentalists, architects, engineers, and programmers should work together [24]. Moreover, there is a growing tendency to integrate evaluation systems, databases, consultants, and suppliers [25]. Also, LCA and BIM integration has been addressed in recent studies [26], mainly focusing on the construction process as it is the most accessible phase of the building life cycle. However, the urbanization process has a significant impact and, although its environmental impact can also be assessed through the BIM project design, has had limited attention from researchers in this field.

In the present work, the state of the art is presented first, starting with the LCA application to the construction process, related normalization and legislation, products, and companies' evaluation strategies and eco-labelling. Software and assessment tools combining the quantitative and qualitative environmental evaluation of projects are also reviewed, as well as different approaches to include LCA and BIM in the environmental impact assessment of architectural projects. Subsequently, a method is proposed for integrating an LCA-enabled construction cost database into a BIM environment to analyse the environmental impact of the urbanization phase of BIM projects. Finally, the case study of an urbanization project supports this proposal, which will allow environmental awareness to be included in this kind of project. In summary, the main objective of this research is to define a methodology to integrate traditional skills into the elaboration of the bill of quantities of construction projects, environmental impact assessments driven by construction cost databases, and project visualization in BIM environments in order to enable their application in urbanization projects.

\section{State of the Art}

\subsection{Life Cycle Assessment (LCA)}

LCA has been widely applied to assess the environmental performance of buildings and the EE and carbon emissions (CE) of their products, materials, and waste [27]. LCA assesses environmental loads throughout the life of a product or service. The International Standards Organization (ISO) created a subcommittee (SC 5) with the purpose of developing international standards to regulate the methodology for calculating universal environmental indicators. The study of the complete life cycle of buildings includes the extraction and processing of raw materials, production, transport and distribution, use, reuse and maintenance, recycling, and final disposal. LCA studies must comply with UNE-ISO 14040 [28] and UNE-ISO 14044 [29]. In Europe, the development of regulations in the field is concentrated on the "Green 7" countries (i.e., those with the highest implementation rates): Austria, Denmark, Finland, Germany, the Netherlands, Sweden, and the United Kingdom. Outside the EU, the most advanced countries in this matter are the USA, Canada, Japan, and Korea [30].

LCA tools, such as SimaPro, Umberto, or GaBi, need simplifications to be accessible to professionals in the AEC (Architecture, Engineering and Construction) industry, since they are not specialized in 
environmental impact assessment [31]. Similarly, the inclusion of primary materials as part of the same material or family constitutes a limitation of a detailed LCA [32], unless the life-cycle inventory includes aggregated materials. This problem is related to the difficulties in defining a framework of necessary parameters to carry out a correct LCA in BIM for the various stages of the life cycle of buildings [26,33].

\subsection{Ecolabels}

Another source of environmental information of construction materials is supplied by producers/manufacturers by means of ecolabels, which add the specific life-cycle data of products. The labels allow access to the positive environmental performance of a product as they are awarded to products with low environmental impact. There are three types: ecolabel type I [34], environmental self-declarations (type II) [35], and environmental product declarations or EPD (type III) [36]. Ecolabels type I are voluntary schemes that affirm the lowest environmental impact of a product. In ecolabels type II, the manufacturer performs the analysis with or without the certification of a competent authority, and ecolabels type III are always verified and define the environmental behaviour of the product. In general, ecolabels assess the extraction and selection of raw materials, production processes (power consumption, water usage and consumption, emissions in the atmosphere and water, etc.), waste management, and emission of hazardous substances.

Ecolabels type III or EPD are defined by UNE-EN ISO 14025 (Labelling Type III: Environmental Product Declarations) and follow a minimum set of ISO standards as well as specific Product Category Rules (PCR). European and many international EPDs also comply with EN 15804 [37]. They can be used as a basis for choosing among products, subject to some limitations. They provide detailed information about specific products, thus improving the accuracy of the LCA of building projects where they are employed. The Embodied Carbon Review Report [38] identified that, from more than 150 green building systems, almost 100 use EPD in their certifications.

EPDs are also related, among other documents, to the European Initiative of Single Market for Green Products [39], the Handbook on Green Public Procurement [30], and the Resolution 2014/2208 about the efficient use of resources [40], which proposes a main indicator and a set of subindicators about the efficient use of resources and ecosystem services. These harmonised indicators measure the consumption of resources, including imports and exports at the EU level, by Member States, and for the industry as a whole, and they consider the entire life cycle of products and services. They are based on the ecological footprint methodology and quantify at least the land, water, materials consumption, and CE.

The main international organizations emitting EPDs are EPD System [41], Product Environmental Footprint (PEF) [42], Sustainable Life [43], ECO-Platform [44], and Level(s) [45]. Specifically, EPD System is an international organization located in Sweden that produces EPDs and Product Category Rules (PCR) for all types of products. It is worth mentioning that EPDs are fully accessible and particular to each company in a specific country.

\subsection{Assessment Tools}

Several sustainability assessment systems and tools have been developed and applied to evaluate the environmental performance of buildings. These can be classified into qualitative and quantitative tools, with the former being easier to apply without specialized knowledge about sustainable construction. Within the former category, the Leadership in Energy and Environmental Design (LEED) and the Building Research Establishment Environmental Assessment Method (BREEAM) are the most relevant, and are continuously updated and revised to meet market demands [46]. Other LCA-based software/tools are Athena, Building Environment Assessment Tool (BEAT), EcoEffect Envest 2, Environmental Load Profile (ELP), Eco-Quantum, and Sustainable Building. Among the quantitative tools, SimaPro, GaBi, and Umberto allow the environmental impact of processes to be calculated from a life-cycle perspective [47]. Two important limitations are as follows: the purchase of costly licenses is required, and much specialized work is involved to perform an LCA. 
Fortunately, there is always an economic control in construction projects, so all the elements involved are usually well defined in terms of their bill of quantities and budget. This is an opportunity for the introduction of environmental indicators as part of the cost assessment. The tools already in place for the cost control of projects can be adapted for sustainability considerations [8,9]. These tools use the cataloguing code employed by Spanish quantity surveyors to obtain the bill of quantities, which eases the implementation and understanding of environmental impact calculation models [48]. Subsequently, activities are broken down into three types of resources: machinery, manpower, and materials. The methodology developed previously by the authors calculates the embodied energy (EE) [49], the carbon footprint (CF) [50-52], and the water footprint (WF) [53,54] of the project, and is suitable for the construction sector thanks to its simplicity and to being introduced as part of the project's budget. The EE, virtual water, and emissions of construction and demolition waste (CDW) management have also been assessed [8].

The previous methodology has been incorporated in two assessment tools: OERCO2 [52] and HEREVEA [55]. The OERCO2 software, which is a result of the OERCO2 Erasmus+ project, is an open-source online tool for the estimation of the CF of new construction residential buildings and is designed to be used by nonspecialized users. Similarly, the HEREVEA tool [55] bases its calculations on the data obtained from the project's bill of quantities to assess the EF of building renovation projects. It also evaluates the economic and environmental feasibility of different proposals simultaneously. The resulting model is then integrated into a geographic information system (GIS), which allows georeferenced results to be obtained. The tool can be used for sustainable and resilient planning, policy-making at all government levels, and decision-making processes. Both types of software have been employed as teaching tools [56,57].

\subsection{BIM and Environmental Assessment}

A general overview of BIM-based tools for environmental impact assessment showed that most of them need to combine the BIM software with other applications to obtain the quantification of environmental indicators. Recently, the advance of BIM worldwide has forced researchers to work on its combination with LCA and LCC (life cycle cost assessment). Various approaches have been followed, which were classified by Santos et al. [26]: those using external individual and separate tools [58]; those connecting quantity take-off and an external LCA database with integrated tools in proprietary software [59]; and the one proposed by Santos et al., based on including LCA and LCC information in BIM models. The main advantage of this last approach is that it quickly updates the analysis results when the project under study is not modified, thus taking advantage of the full potential of BIM tools, while the others require re-exporting the information and re-linking it to the external databases, besides needing extra licenses for the external software involved. In this section, a review of the existing applications regarding these three categories is given to provide a better understanding of the advances in this matter.

\subsubsection{Type 1: Exporting Data to External Tools}

Regarding this first approach, Jalaei and Jrade [60] developed an integration between Autodesk Revit, Microsoft Excel, and Athena Impact Estimator to analyse the environmental impact and the EE of constructive solutions. Marzouk et al. [61] proposed a combination of several software tools (i.e., Autodesk Revit, Revit DB Link, Microsoft Access, and Athena Impact Estimator) for measuring direct and indirect $C E$ in construction projects.

Chen and Pan [62] presented a multicriteria decision-making method for low-carbon construction measures by combining Revit, eQuest, and Promethee [63]. Ajayi et al. [64] explored a combination of Revit Architecture, Green Building Studio (GBS), and Athena complement for global warming potential (GWP) and health impact assessment. Crippa et al. [65] integrated data extracted from Simapro with Excel and ArchiCad to analyse the CF of wall systems in Brazil. A few external applications can import 
and work with data from BIM files. Some examples are Elodie, eTool LCA, GBAT, Impact Compliant Suite, and Lesosai.

\subsubsection{Type 2: Connecting Quantity Take-Off to External LCA Databases through Integrated Tools}

Examples of tools that apply the second approach (i.e., integration into BIM environments as plugins) are LCA Design, Ecotect, Green Building Studio, One Click LCA, and Tally for Autodesk Revit [31]. Specifically, the latter stands out for its intuitive workflow, technical support, and results presented in a useful format. For example, Najjar et al. [66] analysed a case study with the Tally plugin to evaluate the entire life cycle of buildings, aiming to provide recommendations. Schultz et al. [67] studied the differences in the results of LCA from Tally and Athena Impact Estimator, getting similar results but identifying significant differences in the impact categories.

In this line, Basbagill et al. [58] developed a BIM model using DProfiler linked to eQuest within a BIM environment. Subsequently, the results were manually loaded into SimaPro and Athena EcoCalculator to obtain the CF. BIM has also been combined with LEED and BREAM assessments. Azhar et al. [68] combined Revit with IES Virtual Environment to calculate CE and incorporated energy to convert them into LEED credits. Also, Ilhan and Yaman [24] developed a green building evaluation tool using Graphisoft ArchiCAD ${ }^{\circledR}$ linked to the BREEAM material database.

\subsubsection{Type 3: Including Environmental Data in the BIM Model}

Other authors reviewed the existing research on BIM/LCA integration and its possibilities for simplification in terms of input-output data and LCA results [19], and pointed out that the best solution would be to remain within the BIM environment to facilitate the interaction between design and environmental performance assessment [69].

Other environmental evaluation tools and models were defined by Inyim et al. [70], who presented the Simulation of Environmental Impact of Construction (SimulEICon), a BIM extension designed to assist in the design stage of the decision-making process of a construction project. Gan et al. [71] developed a holistic approach to evaluate built-in and operational carbon in high-rise buildings using Revit and a parametric complement, Dynamo. These researchers also evaluated the reduction of the CF by replacing steel and cement with recycled materials [72]. Finally, Yang et al. [73] deployed a unidirectional workflow to calculate the operation and energy of materials and $\mathrm{CO}_{2} \mathrm{eq}$.

\subsubsection{Weaknesses of Other Methods Combining BIM and LCA}

In the three different approaches to combine BIM and LCA described in the state of the art, several weaknesses can be identified. In type 1, the main barrier is that the users' objective is to obtain a certificate from an external tool that also requires additional training and knowledge from the designers. In type 2, the designer also needs to learn an additional tool for the environmental analysis. Finally, type 3 is the simpler strategy because everything happens inside BIM, but it is also the most time-consuming in the definition of each element's impact, since LCA data are introduced directly into the BIM software. Thus, if the BIM model changes in any of its components, new LCA data need to be calculated and integrated.

\subsection{Reliability}

As stated in the previous sections, data processing depends on the quality and accessibility of LCA, which vary depending on the source, as presented in Figure 1. Accessibility is when manufacturers make their LCA public. This can be done by using ecolabels, such as EPD, or by less product-specific data, such as the generic data that can be obtained from LCA databases, thus losing reliability [74]. Its robustness depends on the reliability of the consulted sources, since each manufacturer defines the degree of confidence of data by choosing the ecolabel for their products. 


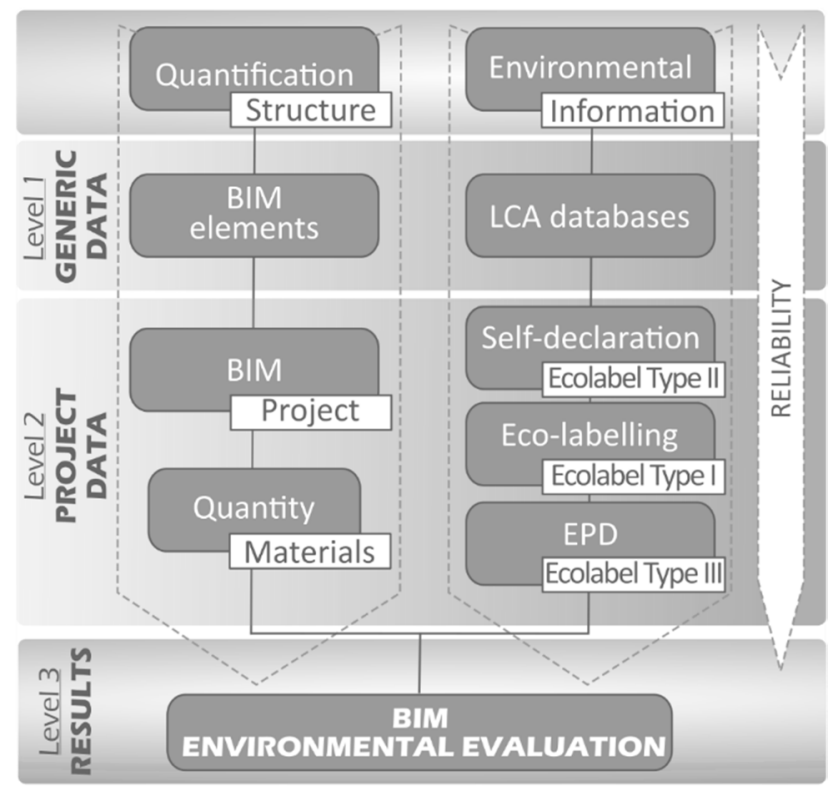

Figure 1. Reliability of the economic and environmental assessment of construction projects.

In Figure 1, the first level corresponds both to generic BIM elements for the representation of the project and to generic environmental information of products. In the second level, the previous data are adapted to an actual project by defining the geometry, descriptions, and components with BIM, based on the quantity take-off and using more transparent and product specific environmental data from ecolabels. In the third level, environmental indicators or footprints can be calculated and represented for each work unit previously defined in the project. In the last level, the information can be added to the BIM model by means of plugins, directly inserted in the BIM software or by sending the BIM information to environmental assessment tools.

Another important aspect is the type of information usually presented in construction projects. These projects employ construction cost databases both to generate and control project budgets and to define a structure and measurement criteria, which are contractually binding and agreed upon in the sector by contractors, designers, and suppliers. To define work units, construction work breakdown systems (WBS) are mainly used. The WBS divides the construction project into small parts that can be easily combined. The most representative are: Standard Method of Measurement of Civil Engineering [75], Uniformat [76], Uniclass [77], ISO 12006-2 [78], and MasterFormat [79].

This widespread tool is a suitable means to introduce environmental assessment in engineering and architecture. In Spain, highly specialized platforms, such as the BEDEC cost database, SOFIAS or E2CO2Cero tools, allow $\mathrm{CO}_{2}$ emissions to be calculated in detail according to the project's bill of quantities. BEDEC was developed by the Institute of Construction Technology of Catalonia [80] and uses environmental data of building materials from the Ecoinvent LCA database [81], one of the most complete databases at the European level [74], which is integrated in the Simapro LCA software [82]. As for the SOFIAS tool, environmental data are obtained from OpenDAP [83]. An intermediate approach is defined in E2CO2Cero by the Basque Country Government in Spain. This approach allows energy and carbon emissions to be calculated due to the materials and processes employed during the building construction [84].

Databases clearly define what should be measured and how it must be done with BIM objects. Therefore, providers must match their environmental information with the way products are traditionally measured and included in the project budgets. This method can be a reliable way of including environmental assessment in construction. The measurement criteria of cost databases can match the quantities obtained from BIM and, simultaneously, the criteria employed in the definition of 
construction or work units and products by the market, such as square metres of the floor area covered by tiles or cubic metres of concrete in a column.

Another interesting aspect of construction cost databases is the definition of all the subelements of each work unit. These databases come from a long tradition of cost control in the construction sector, since each element and its quantities are contractually binding. The accurate quantity take-off BIM provides an essential aspect of the environmental impact assessment of projects. Interoperability to determine the amount of material and a cost estimation can accelerate the design process, aid the comparison of alternative solutions, and produce better results [85]. This was already done by Abanda et al. [86], who developed a specific application to link BIM models with the New Measurement Rules (NMR) in the UK standard for public procurement [87] by using the Bath Inventory of Carbon and Energy (Bath ICE) [88]. Also, Mercader-Moyano et al. [89] applied an environmental impact assessment to a BIM environment by using a construction cost database for the quantity take-off.

\section{Materials and Methods}

In this section, a method for the calculation of the $\mathrm{CF}, \mathrm{WF}$, and $\mathrm{EE}$ of urbanization projects is presented. The CF indicator is widely used in the construction sector [90]. However, there are limitations on CF calculations that make the results difficult to compare because the methodologies do not follow a unified international standard [91]. Several examples of the application of the CF indicator to construction projects $\mathrm{CF}$ have been carried out using the projects' bill of quantities [50-52]. In recent years, advances have been made in defining ranges for the $\mathrm{CO}_{2}$ of construction elements to make the results comparable [92].

The other two indicators considered in this model, EE [49] and WF [53,54], are of interest to the construction sector due to the simplicity of their message. The EE represents the energy efficiency of the production of products and is independent from the emissions accounting. It is also a useful indicator in construction project assessment [49]. The WF is another interesting indicator to analyse because it determines the amount of this scarce resource employed in the production of goods, being an increasingly important impact in manufacturing. It was developed and standardised following the publication of The Standard Calculation Methodology [93] and The Water Footprint Assessment Manual [94], and is currently disseminated by the Water Footprint Network [95].

The proposed methodology starts with a comprehensive description of the construction project. All the elements in the project should be neatly defined to correctly determine the amount of resources to be consumed. To this end, the WBS of Andalusia Construction Cost Database (ACCD) [96] is used. The ACCD has a bottom-up organization, with the completed project being the highest level of the hierarchy [48]. Each work unit has an associated unit cost and all its components (materials, machinery, and manpower) are described and quantified. The description of these components by an alphanumeric code, which groups units by the material nature or type of common workforce, facilitates the calculation not only of their cost but also of their quantities for similar work units. The levels and examples are illustrated in Figure 2A. On the other hand, measurement criteria are included in each unit description and their subelements in Figure 2B. The set cost per work unit is reinforced by establishing a singular relationship between the measurement criteria established for a given work unit and its corresponding cost. As a result, if the criteria are modified, the cost must be changed. Common measurement units (cubic metre, square metre, thousand units, etc.) are used for similar work units.

Once all the elements necessary to the construction project are codified, information about the nature of each element can be gathered. For example, elements whose code starts with $\mathrm{CH}$ are all made of concrete of a certain type, so their impact is assigned from LCA databases. The weight of each material can be determined by their quantities, obtained through the geometry of BIM construction objects. Each step is explained in detail in the following paragraphs. 
A)

\section{Complex Cost $(\mathrm{CC})$}

Aggregation of unitary elements

e.g., 15 PCC 10500

$\mathrm{m}^{3}$ Concrete pavement with polypropylene fibres HM-25/P/40/I

Unit Cost (UC)

Group division into unitary elements

e.g., 03 HMM00014

$\mathrm{m}^{3}$ Mass concrete HM-25 with polyethylene fibre for flooring

Auxiliary Cost (AC)

Main stages

of a dwelling construction project

e.g., 15. Urbanisations

Combination of elements frequently used in different work units

e.g., ATC01200. h Masonry quadrille

Basic Cost (BC)

Chapter

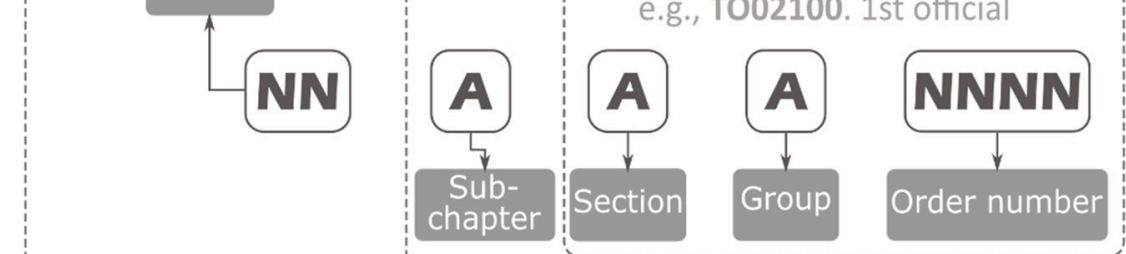

applied on site

e.g., T002100. 1st official

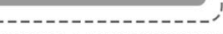

\begin{tabular}{|l|l|l|r|r|r|}
\hline $15 P C C 10500$ & $\mathrm{~m}^{3}$ & CONCRETE PAVEMENT WITH POLYPROPYLENE FIBRES HM-25/P/40/1 & TOTAL $€$ & 106.58 \\
\hline
\end{tabular}

\begin{tabular}{|c|c|c|c|c|c|}
\hline CODE & u & CONCEPT & Q & $\cos T$ & AMOUNT \\
\hline TP00100 & $\mathrm{h}$ & SPECIAL PEON & 0.20 & 18.90 & 3.78 \\
\hline 03НMM00014 & $\mathrm{m}^{3}$ & MASS CONCRETE HM- 25 WITH POLYETHYLENE FIBRE FOR FLOORING & 1.00 & 91.74 & 91.58 \\
\hline ME00200 & $\mathrm{h}$ & PAVING MACHINE & 0.03 & 17.98 & 0.63 \\
\hline MК00100 & $\mathrm{h}$ & DUMP TRUCK & 0.35 & 25.60 & 8.96 \\
\hline MR00400 & $\mathrm{h}$ & VIBRATING ROLLER & 0.07 & 23.28 & 1.63 \\
\hline
\end{tabular}

\begin{tabular}{|c|c|c|c|c|c|c|c|c|c|}
\hline 03НMM00014 & $\mathrm{m}^{3}$ & \multicolumn{6}{|c|}{ MASS CONCRETE HM-25 WITH POLYETHYLENE FIBRE FOR FLOORING } & TOTAL € & 91.74 \\
\hline \multicolumn{10}{|c|}{$\begin{array}{l}\text { Paving with mass concrete } \mathrm{HM}-25 / \mathrm{P} / 40 / \mathrm{I} \text {, including outstretched with vibrating screed. } \\
\text { Measured theoretical volume. }\end{array}$} \\
\hline CODE & u & \multicolumn{5}{|c|}{ CONCEPT } & Q & COST & AMOUNT \\
\hline ATC01200 & $\mathrm{h}$ & \multicolumn{5}{|c|}{ MASONRY QUADRILLE } & 0.20 & 57.79 & 2.89 \\
\hline $\mathrm{CH} 45020$ & $\mathrm{~m}^{3}$ & \multicolumn{5}{|c|}{ CONCRETE HM-25/P/40/I, WITH POLYETHYLENE FIBRES } & 1.05 & 75.96 & 79.76 \\
\hline MR00500 & $\mathrm{h}$ & \multicolumn{5}{|c|}{ VIBRANT RULE } & 0.133 & 3.21 & 0.43 \\
\hline \multirow[t]{6}{*}{$\rightarrow$} & ATC & 01200 & h & \multicolumn{4}{|c|}{ MASONRY QUADRILLE } & TOTAL $€$ & 57.79 \\
\hline & \multicolumn{9}{|c|}{$\begin{array}{l}\text { Masonry quadrille formed by 1st official, specialist assistant and special peon. } \\
\text { Measurement of working hours }\end{array}$} \\
\hline & \multicolumn{2}{|c|}{ CODE } & u & \multicolumn{3}{|c|}{ CONCEPT } & $\mathbf{Q}$ & COST & AMOUNT \\
\hline & \multicolumn{2}{|c|}{ TO02100 } & $\mathrm{h}$ & \multicolumn{3}{|c|}{ 1st OFFICIAL } & 1.00 & 19.85 & 19.85 \\
\hline & \multicolumn{2}{|c|}{ TP00100 } & $\mathrm{h}$ & SPECIA & PEC & & 1.00 & 18.90 & 18.90 \\
\hline & \multicolumn{2}{|c|}{ TA00100 } & $\mathrm{h}$ & SPECIA & IST & SSISTANT & 1.00 & 19.04 & 19.04 \\
\hline & \multicolumn{4}{|c|}{$\rightarrow \mathrm{T} 002100$} & h & 1st OFICIAL & & TOTAL € & 19.85 \\
\hline
\end{tabular}

Figure 2. (A) Construction work units are classified according to the ACCD; (B) a complex unit cost is divided into subelements for illustration purposes.

From each machine employed in the project, fuel consumption is considered its main environmental impact, which is linked to its engine power (fuel and electricity) and working hours [97]. The average 
fuel consumption of machines is from 0.15 to 0.20 for diesel engine, and from 0.30 to $0.40 \mathrm{~L} / \mathrm{h} / \mathrm{kW}$ for petrol [98].

The fuel consumed is obtained as specified in Equation (1):

$$
\mathrm{V}=\mathrm{P} \times \mathrm{Wh} \times \mathrm{R},
$$

where V: Fuel consumption (L); P: Engine power (kW); Wh: Working hours (h); and R: Engine performance $(\mathrm{L} / \mathrm{kWh})$.

As for electrical machines, energy consumption is calculated as defined in Equation (2):

$$
\mathrm{C}=\mathrm{P} \times \mathrm{Wh} \times \mathrm{C}_{\mathrm{f}},
$$

where C: Consumption (GJ); P: Power (kW); Wh: Working hours (h); and Cf: Conversion factor $(\mathrm{GJ} / \mathrm{kWh})$.

WF for machines and trucks is $13.60-28.32 \mathrm{~m}^{3} / \mathrm{h}$, respectively; EE is $1090.36-2271.36 \mathrm{MJ} / \mathrm{h}$, and CF is 62.78-130.80 $\mathrm{tCO}_{2} \mathrm{eq} / \mathrm{h}$ [8]. To obtain the $\mathrm{CO}_{2}$ emissions, water consumption, and EE of construction materials, their Life Cycle Inventory (LCI) is analysed by applying the IPCC 100a and Water Footprint and Cumulative Energy Demand methodologies provided with Simapro v8. The environmental information is extracted from the EcoInvent database through SimaPro, since this database covers the vast majority of materials usually employed in construction [6].

In the BIM project, the quantities of construction materials (Qi) are determined, e.g., the number of benches, the cubic metres of concrete in the road, or the square metres of tile area in a sidewalk. When the environmental impacts of each work unit are already included in the ACCD, see Figure 3, they can be multiplied to obtain the total impact of the element or unit cost, as shown in Equation (3):

$$
\mathrm{I}_{\mathrm{i}}=\mathrm{Q}_{\mathrm{i}} \times \mathrm{U}_{\mathrm{i}}
$$

where $\mathrm{I}_{\mathrm{i}}$ is the impact (WF, EE or $\left.\mathrm{CF}\right)$, and $\mathrm{U}_{\mathrm{i}}$ is the total impact in the construction unit $\mathrm{i}$.

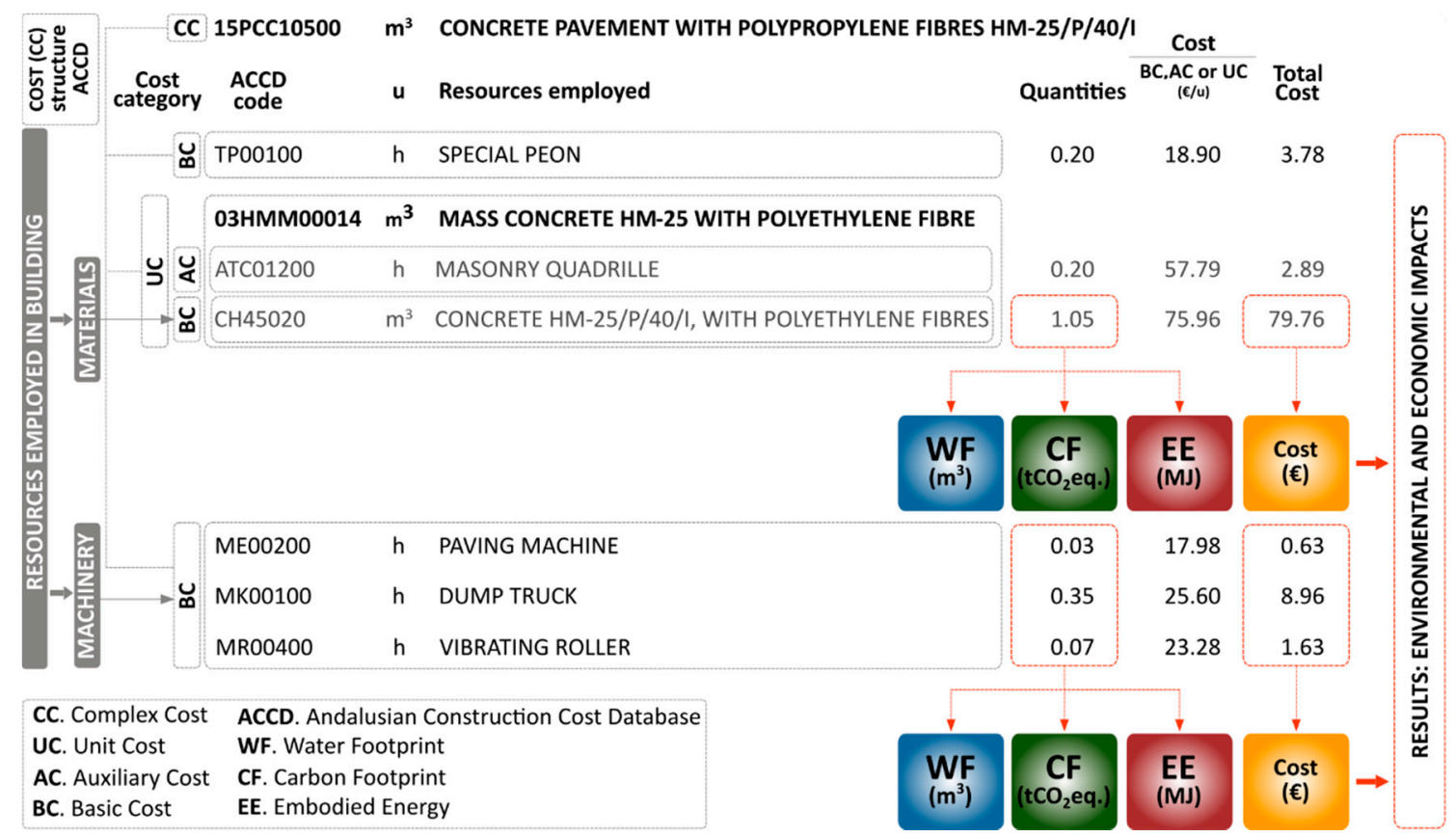

Figure 3. Structure of environmental and economic impacts according to the ACCD. 
The proposed methodology is represented in Figure 4.

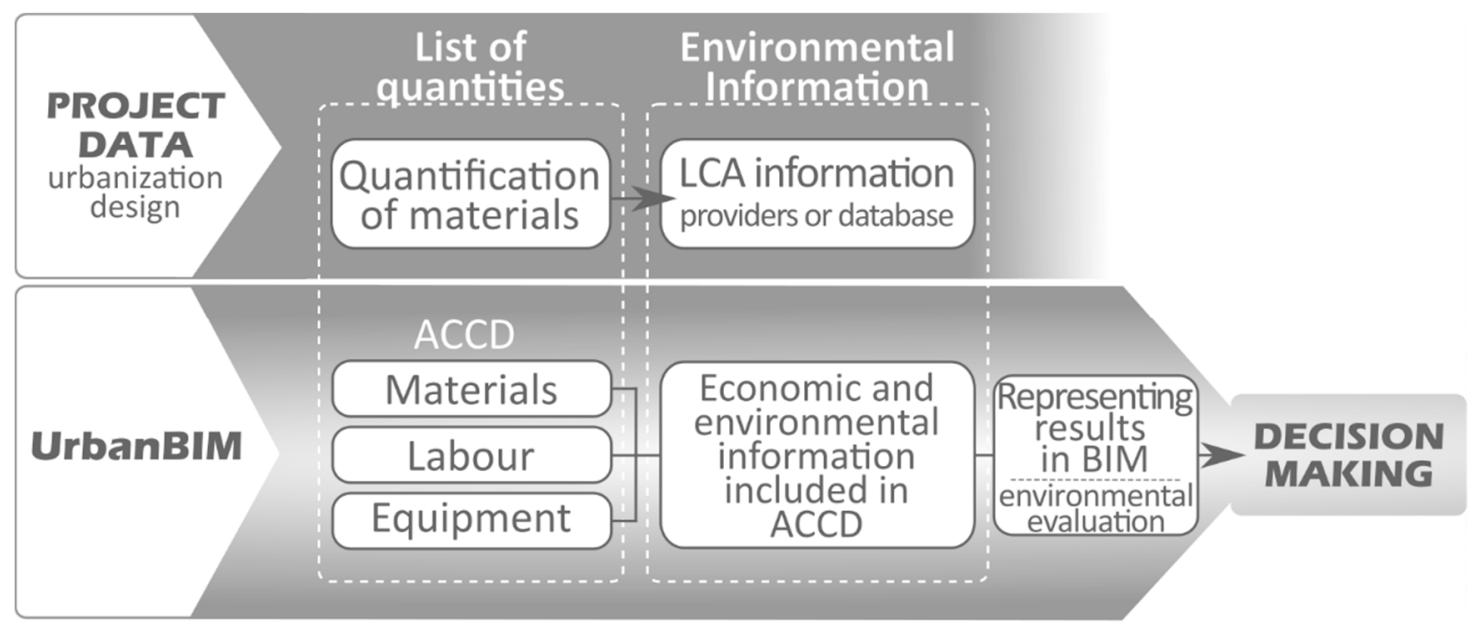

Figure 4. The methodology proposed in the UrbanBIM project for the inclusion of environmental data in urbanization projects by means of the ACCD.

\section{Results}

In public spaces, playgrounds and parking lots are useful for the introduction of environmental awareness to the urban planning of cities. For this, a small urbanization project is defined for the illustration of the proposed methodology. The project includes a playground (12 $\mathrm{m} \times 22 \mathrm{~m})$, a parking lot $(20 \mathrm{~m} \times 22 \mathrm{~m})$, a section of road $(40 \mathrm{~m} \times 6 \mathrm{~m})$, the corresponding sidewalk $(40 \mathrm{~m} \times 2 \mathrm{~m})$, and a cycle path $(40 \mathrm{~m} \times 2 \mathrm{~m})$. As expected for this type of construction site, concrete and asphalt are the main materials but others are also used, such as wood for benches and metal for the playground and street lighting.

As Table 1 shows, it was possible to define classification equivalences between BIM (or IFC) elements, codes from Uniclass, and complex costs (CC) from the ACCD, thus calculating their environmental impact in terms of the three indicators considered in this study, i.e., $\mathrm{EE}, \mathrm{CF}$, and WF. A short description of each CC, along with their economic cost and environmental impact, is also shown in Table 1 . The 19 CC defined for the case study comprised 68 unit costs (UC). For each, the unit impact was determined by adding the impact of their basic components (BC). The complete list of the elements included in these CC is presented in Table A1 of Appendix A, with the corresponding cost and environmental impact.

After connecting the CC to the BIM model of the urbanization project, those elements that should be first addressed to reduce the project's WF, EE, or CF were visually identified (see Figure 5). BIMVision software by Datacomp was employed to represent the results. The software was combined with a plug-in specifically created to visualize the environmental impact of each element in the model, which was part of the deliverables of the UrbanBIM Erasmus+ project. As Figure 5 shows, in the specific case of the $\mathrm{CF}$, the parking area and the sidewalk generated the greatest impacts, even though their unitary impacts were low (see Table 1). Similar results were obtained from the other two indicators (WF and EE); again, two big elements, the parking lot, as previously mentioned, and the driveway had the highest impact. The incorporation of bituminous materials (from petroleum) and tars (from coal) into the road pavement involved the incorporation of very significant amounts of $\mathrm{EE}$, and, in the case of aggregates, high water consumption. 
Table 1. Unit cost and environmental impact of BIM elements in the urbanization project.

\begin{tabular}{|c|c|c|c|c|c|c|c|c|c|}
\hline IFC Element & $\begin{array}{l}\text { ACCD } \\
\text { Code }\end{array}$ & Uniclass & Description & $\begin{array}{c}\text { Street } \\
\text { Element }\end{array}$ & $\mathbf{U}$ & $\begin{array}{c}\text { Cost } \\
(\mathrm{EUR} / \mathrm{U})\end{array}$ & $\begin{array}{c}\mathrm{CF} \\
\left(\mathrm{tCO}_{2} \mathrm{eq} / \mathrm{U}\right)\end{array}$ & $\begin{array}{c}\text { WF } \\
\left(\mathrm{m}^{3}{ }_{\text {water }} / \mathrm{U}\right)\end{array}$ & $\begin{array}{c}\mathrm{EE} \\
(\mathrm{MJ} / \mathrm{U})\end{array}$ \\
\hline \multirow{5}{*}{ IfcSlab } & 15РPP50120 & EF_30_60 & \multirow{5}{*}{$\begin{array}{l}\text { Pavement in parking area with paving blocks } \\
\text { Pavement in children's play area with artificial } \\
\text { grass and absorbent base } \\
\text { Sidewalk with concrete paving blocks } \\
\text { Cycle paths } \\
\text { Bituminous concrete driveway }\end{array}$} & Pavement & $\mathrm{m}^{2}$ & 54.37 & 0.078 & 1.2 & 492 \\
\hline & 15PРP50250 & EF_30_60 & & Pavement & $\mathrm{m}^{2}$ & 41.21 & 0.025 & 1.6 & 372 \\
\hline & 15РPР50110 & EF_30_60 & & Sidewalk & $\mathrm{m}^{2}$ & 31.91 & 0.081 & 1.3 & 471 \\
\hline & 15PPP50180 & EF_30_60 & & Cycle path & $\mathrm{m}^{2}$ & 33.22 & 0.098 & 2 & 670 \\
\hline & 15РPР50110 & EF_30_60 & & Driveway & $\mathrm{m}^{2}$ & 22.64 & 0.047 & 1.9 & 515 \\
\hline \multirow{2}{*}{ IfcTank } & 15ADD50005 & Pr_60_50_96_15 & Rainwater tank & Tanks & $\mathrm{m}^{3}$ & 552.57 & 1.207 & 66.6 & 9702 \\
\hline & 15UR50050 & Pr_40_50_07_22 & Underground container, 4000 litres & Container & $\mathrm{u}$ & 5950.12 & 6.719 & 584.8 & 34709 \\
\hline \multirow{9}{*}{ IfcUrbanFurniture } & 15ЕРР00105 & Pr_70_70_48_73 & Galvanized steel streetlight 6 m LEDS light & Streetlight & $\mathrm{u}$ & 1023.07 & 3.425 & 71 & 56602 \\
\hline & 15UPA0010 & Pr_40_30_29 & Bench, metallic support and Nordic pine seat & Bench & $\mathrm{u}$ & 256.29 & -0.041 & 0.2 & 656 \\
\hline & 15URP00010 & Pr_40_50_07_96 & Metallic public bin & Bin & $\mathrm{u}$ & 457.78 & 0.271 & 4.3 & 1979 \\
\hline & 15UPA0005 & Pr_40_30_29 & White concrete bench & Bench & $\mathrm{u}$ & 940.84 & 2.052 & 28.1 & 13532 \\
\hline & 15UFF50010 & Pr_40_20_87_24 & Drinking fountain & Fountain & $\mathrm{u}$ & 1379.35 & 0.066 & 107.3 & 6685 \\
\hline & 15UFF50011 & Pr_70_55_98_30 & Street fountain & Fountain & $\mathrm{u}$ & 45732.76 & 25.402 & 5457 & 363223 \\
\hline & 15UPB00100 & Pr_40_30_61_88 & Children's seesaw & Seesaw & $\mathrm{u}$ & 1005.29 & 0.396 & 7.4 & 4848 \\
\hline & 15CSS50120 & Pr_70_75_70_14 & Transfer traffic light, $6 \mathrm{~m}$ high & Traffic light & $\mathrm{u}$ & 4589.57 & 2.24 & 78.9 & 25973 \\
\hline & 15CRR10102 & Pr_70_75_72_30 & Vertical traffic sign & Sign & $\mathrm{u}$ & 114.12 & 0.31 & 6.1 & 4513 \\
\hline IfcPipeSegment & 15ACW50110 & Pr_65_52 & Ceramic pipe DN 600 & Pipe & $\mathrm{m}$ & 211.39 & 0.278 & 17.2 & 5300 \\
\hline \multirow{2}{*}{ IfcFooting } & 15ACV50140 & Pr_65_52_07_89 & \multirow{2}{*}{$\begin{array}{l}\text { Trench to draining pipe DN } 200 \text { up to } 3 \mathrm{~m} \text { deep } \\
\text { Concrete well for DN } 600\end{array}$} & Trench & $\mathrm{m}$ & 138.46 & 0.1464 & 26.1 & 3382 \\
\hline & 15 APP50145 & Pr_65_52 & & Well & $\mathrm{u}$ & 1126.88 & 1.8605 & 101.4 & 15380 \\
\hline
\end{tabular}




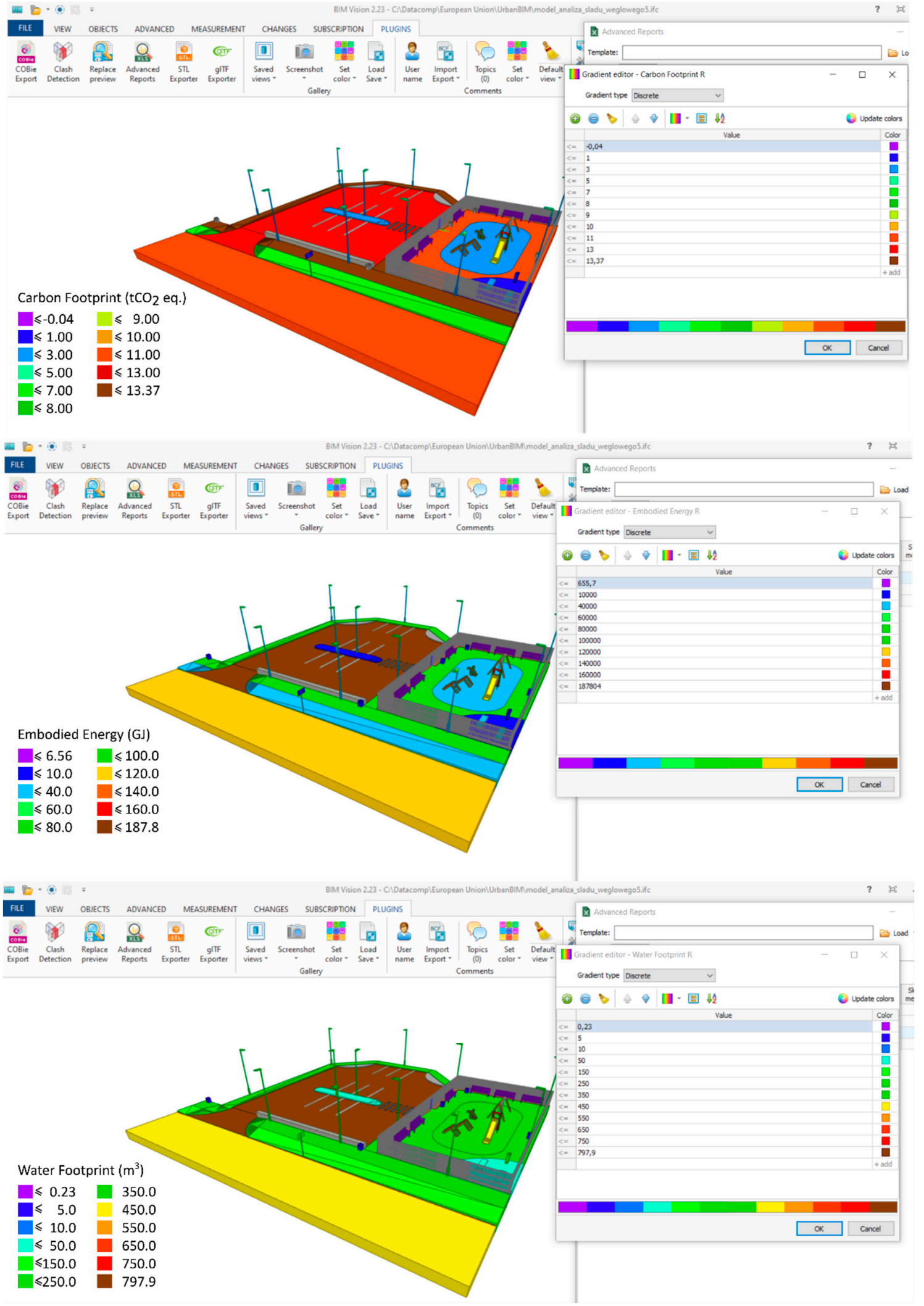

Figure 5. The urbanization project is represented in BIM, and the elements are coloured by their impact intensity: (from top to bottom) CF, EE, and WF.

The smallest impact was based on each wooden bench, a small element in the project that was made of a low-impact material. However, the size was not the only defining aspect: for example, 
the cycle path and the sidewalk had similar sizes but the CF impacts were represented in different colours (green and brown, respectively). This indicated that the concrete tiles placed on the sidewalk had a greater impact than the poured concrete used in the cycle path. The tiles also had more impact than the biggest element in the project, the driveway. In the results obtained by Freire et al. [9], asphalt and concrete were also the highest-impact materials in the evaluation of urbanization projects.

The methodology could be extrapolated to a complete construction cost database to define the BIM model and its impact with a tool based on cost control. The biggest difficulty is the amount of information to be transformed. In the case of the ACCD, this needs to be done for over 7000 elements. The big advantage is that the indicators selected are easy to understand, and some degree of automation can be achieved.

\section{Discussion}

This study shows that it is possible to incorporate ecological indicators, such as WF, CF, and EE, into the classification system of construction cost databases through the methodology developed by the ArDiTec research group. When working on the sample urbanization project, the definition and use of new work units, complex and unit costs were required to integrate them into the ACCD classification system, specifically the urbanization chapter of the work breakdown system, which is focused on the elements related to the connections of buildings with urban networks.

The elaboration of a calculation matrix with the environmental data obtained from the LCA databases for each element, which was part of the various work units, became necessary, thus making it possible to carry out the assessment through the developed plugin for the employed BIM environment. The correct definition of the system boundaries and their components by means of the work units and their elements avoided the gaps andoverlaps that usually happen in construction cost assessment.

The design of the system was totally transparent, resulting in an easy and intuitive tool. A major challenge was to define the BIM elements properly to match the work units. Lützkendorf et al. [85] found that BIM could determine the amount of materials and cost estimation, which can be helpful for the environmental assessment. Mercader-Moyano et al. [89] applied a different strategy by combining costs with the environmental assessment using BIM to define the composition of work units in the case of a reinforced concrete structure. The amount and section of the reinforcement bars was then represented in the BIM elements, and their environmental assessment was calculated. Rock et al. have also studied how to combine BIM, a cost database in Switzerland, and its work classification system in the environmental assessment of building construction [99]. This also identified the importance of concrete in buildings.

The most important contribution of the present work, besides showing how the LCA can be graphically represented in urbanization projects, is that traditional construction cost databases are proven to be an instrument for the introduction of environmental assessment to the construction sector, since its use is widespread and agreed on by stakeholders in the sector, such as constructors, promoters, engineers, and architects. The way elements are traditionally measured in the market becomes the key to defining the LCA data associated with them. In urbanization projects, as well as in building construction, cost data can be employed both to define the BIM model and to obtain the bill of quantities.

There are also limitations to this study: in order to implement BIM and environmental assessment in urbanization projects, it is necessary to have a combined strategy for the standardization of work units, together with the breakdown systems for information classification. It is also necessary to have a clear definition of the system boundaries in order to compare different projects. For this, all construction units in the cost databases need a regularized methodology of environmental impact assessment. 


\section{Conclusions}

Scattered urbanization projects are frequent in cities; the basic components are repeated in many of them, but because of small sizes, the introduction of an environmental assessment is difficult at the moment. Nevertheless, cost control always takes place in publicly funded projects. This helps to introduce the assessment by combining BIM representation with construction cost databases.

The databases, their internal cost structure, and a classification of works allow the resources employed in a project to be determined accurately. Classification equivalences make it possible to include the calculation of environmental indicators, i.e., EE, CF, and WF. Construction cost databases and environmental assessment could be combined by defining the equivalence between BIM elements and their corresponding unit costs.

Data processing depends on the quality and accessibility of LCA data, which vary depending on the source: eco-labelling, such as EPD, or less product-specific data, such as generic LCA databases. Moreover, the robustness depends on the reliability of the sources consulted, since each manufacturer, by choosing an eco-label for their products, defines the degree of confidence of the data provided. The previous data are adapted to a specific project by defining the geometry of BIM objects. Also, environmental indicators or footprints can be calculated and represented for each construction unit previously defined in the project. The information can then be added to the BIM model through plugins, directly inserted in the BIM software or sent to environmental assessment tools.

One of the biggest setbacks to the environmental evaluation of projects in BIM is the complexity of the information, as the LCA integration with BIM requires programming skills, thus making the assessment a multidisciplinary task necessitating that environmentalists, architects, engineers, and programmers work together. The construction cost databases traditionally used in the sector to generate and control the project budgets define a structure and measurement criteria for each work unit, which is contractually binding and agreed upon in the sector by constructors, designers, and suppliers. This becomes an opportunity for introducing environmental awareness and an economic control into the sector, supported by BIM visualization tools.

In forthcoming research studies, other type of projects could be assessed, from single housing to high-rise buildings, to analyse in detail the limitations and opportunities of combining BIM, cost, and environmental analysis. Also, the different stages of the building life cycle can be addressed using the proposed methodology by assessing construction or successive renovation or maintenance projects that take place during the life span and the corresponding budgets.

Author Contributions: Conceptualization, M.M.; methodology, M.M.; software, M.W.; validation, M.M. and A.M.-R.; writing — original draft preparation, M.M.; writing — review and editing, A.M.-R. and J.S.-G.; visualization, M.D.A.-R. All authors have read and agreed to the published version of the manuscript.

Funding: This paper and the costs for its publication in open access have been funded by the URBANBIM project (code 2018-1-RO01-KA203-049458), an ERASMUS+ project co-funded by the European Union and within the framework of an initiative of 2018 (KA2, Strategic partnerships in the field of higher education), with the support of the Servicio Español Para la Internacionalización de la Educación (SEPIE, Spain). This research was funded by the ERASMUS+ Programme and the VI Own Research and Transfer Plan of the University of Seville (VI PPIT-US).

Conflicts of Interest: The authors declare no conflict of interest. The funders had no role in the design of the study; in the collection, analyses, or interpretation of data; in the writing of the manuscript, or in the decision to publish the results. The European Commission's support for the production of this publication does not constitute an endorsement of the contents, which reflect the views only of the authors, and the Commission cannot be held responsible for any use which may be made of the information contained therein. 


\section{Appendix A}

Table A1. Cost and environmental impact per work subunit of the street urbanization, including the main construction units represented in bold characters.

\begin{tabular}{|c|c|c|c|c|c|c|c|}
\hline ACCD Code & Description & $\mathrm{U}$ & Quantity & Cost (EUR/U) & $\mathrm{CF}\left(\mathrm{tCO}_{2} \mathrm{eq} / \mathrm{U}\right)$ & WF $\left(\mathrm{m}^{3}\right.$ water $\left./ \mathrm{U}\right)$ & $\mathrm{EE}(\mathrm{MJ} / \mathrm{U})$ \\
\hline 15ACW50110 & Ceramic pipe DN 600 & $\mathrm{~m}$ & & 211.39 & 0.278 & 17.2 & 5300 \\
\hline 15ACW91110 & Vitrified ceramic pipe $600 \mathrm{~mm}$ & $\mathrm{~m}$ & 1 & 172.52 & 0.2437 & 10.1379 & 4750.6 \\
\hline 15MMG90210 & Trench-fill with granular material. Manual means & $\mathrm{m}^{3}$ & 0.95 & 16.61 & 0.0241 & 2.5613 & 330.4 \\
\hline 15MMW90152 & Trench-fill with sand. Mechanical means & $\mathrm{m}^{3}$ & 1.085 & 14.23 & 0.0155 & 0.2735 & 87.1 \\
\hline 15MZZ90125 & $\begin{array}{l}\text { Mechanical trench excavation in urbanized area > } \\
2.50 \mathrm{~m}\end{array}$ & $\mathrm{~m}^{3}$ & 2.378 & 4.20 & -0.0079 & 4.2167 & 126.9 \\
\hline 15MWW00210 & Trench and manhole shoring & $\mathrm{m}^{2}$ & 3.886 & 3.83 & 0.0026 & 0.0106 & 5 \\
\hline 15APP50145 & Concrete manhole for DN 600 & $\mathbf{u}$ & & 958 & 1.9337 & 24.4064 & $12,877.9$ \\
\hline 15MPP90125 & Mechanical excavation in urbanized area $>2.50 \mathrm{~m}$ & $\mathrm{~m}^{3}$ & 12.5 & 6.65 & -0.0125 & 6.6261 & 199.4 \\
\hline 15АРP00145 & $\begin{array}{l}\text { Prefabricated circular manhole diam. } 1.20 \mathrm{~m} \text {, depth } \\
\qquad>2.50 \mathrm{~m}\end{array}$ & $\mathrm{u}$ & 1 & 931.94 & 1.9271 & 17.3828 & $12,583.4$ \\
\hline 15MMW90160 & Manhole-fill with sand. Mechanical means & $\mathrm{m}^{3}$ & 2.262 & 15.58 & 0.0165 & 0.3869 & 90.1 \\
\hline 15MWW00210 & Trench and manhole shoring & $\mathrm{m}^{2}$ & 20 & 3.83 & 0.0026 & 0.0106 & 5 \\
\hline 15ADD50005 & Rainwater tank & $\mathrm{m}^{3}$ & & 552.57 & 1.2065 & 66.5697 & 9702.4 \\
\hline 15MPP90115 & Manual excavation in urbanized area $>2.50 \mathrm{~m}$ & $\mathrm{~m}^{3}$ & 1.088 & 32.83 & -0.0606 & 30.1147 & 906.4 \\
\hline 15MPP90125 & Mechanical excavation in urbanized area $>2.50 \mathrm{~m}$ & $\mathrm{~m}^{3}$ & 2.538 & 6.65 & -0.0125 & 6.6261 & 199.4 \\
\hline 15MTW00005 & $\begin{array}{c}\text { Internal transport of material from excavation. } \\
\text { Manual means }\end{array}$ & $\mathrm{m}^{3}$ & 1.088 & 5.86 & 0 & 0 & 0 \\
\hline 15MTW00010 & $\begin{array}{l}\text { Internal transport of material from excavation. } \\
\text { Mechanical means }\end{array}$ & $\mathrm{m}^{3}$ & 2.538 & 0.17 & 0.0004 & 0.0004 & 0 \\
\hline 15MWW90160 & Manhole-fill with sand. Mechanical means & $\mathrm{m}^{3}$ & 1.088 & 15.58 & 0.0165 & 0.3869 & 90.1 \\
\hline 15MWW00210 & Trench and manhole shoring & $\mathrm{m}^{2}$ & 1.845 & 3.83 & 0.0026 & 0.0106 & 5 \\
\hline 03НММ00012 & Blinding concrete HM-20/P/40/I & $\mathrm{m}^{3}$ & 0.051 & 70.55 & 0.2417 & 3.6014 & 1333.6 \\
\hline 03HAL00715 & Concrete HA-25/P/20/IIa in foundation & $\mathrm{m}^{3}$ & 0.254 & 74.7 & 0.2927 & 4.3723 & 1606.8 \\
\hline 03НАM00750 & Concrete HA-25/B/20/IIa in walls & $\mathrm{m}^{3}$ & 0.414 & 73.3 & 0.2959 & 4.4155 & 1627.8 \\
\hline 03HAL00765 & Concrete HA-25/B/20/IIa in slabs & $\mathrm{m}^{3}$ & 0.152 & 77.74 & 0.2961 & 4.4173 & 1631.7 \\
\hline 03АCC00811 & B500S corrugated steel bars & $\mathrm{kg}$ & 80.986 & 1.49 & 0.0016 & 0.0295 & 25.5 \\
\hline 03ERM00011 & Wooden formwork for foundation & $\mathrm{m}^{2}$ & 0.217 & 9.76 & -0.0115 & 5.5177 & 166.1 \\
\hline 03ERT00011 & Metallic formwork for foundation & $\mathrm{m}^{2}$ & 1.379 & 26.31 & -0.0067 & 4.6274 & 183.2 \\
\hline 15ASW00100 & Polyethylene manhole step & $\mathrm{u}$ & 0.386 & 19.16 & 0.0067 & 0.1877 & 208.2 \\
\hline 15ASW00170 & Manhole cover, diam. $400 \mathrm{~mm}$ & $\mathrm{u}$ & 0.027 & 84.87 & 0.0972 & 0.9414 & 981.5 \\
\hline 03EWW00025 & Steel grating (tramex) & $\mathrm{m}^{2}$ & 0.207 & 49.77 & 0.0464 & 1.3208 & 737.1 \\
\hline
\end{tabular}


Table A1. Cont.

\begin{tabular}{|c|c|c|c|c|c|c|c|}
\hline ACCD Code & Description & $\mathbf{U}$ & Quantity & Cost (EUR/U) & $\mathrm{CF}\left(\mathrm{tCO}_{2} \mathrm{eq} / \mathrm{U}\right)$ & $\mathrm{WF}\left(\mathrm{m}^{3}\right.$ water $\left./ \mathrm{U}\right)$ & $\mathrm{EE}(\mathrm{MJ} / \mathrm{U})$ \\
\hline 15UR50050 & Underground container, $4000 \mathrm{~L}$. & $\mathbf{u}$ & & 4241.46 & 5.8402 & 164.4954 & $89,718.1$ \\
\hline 15MPР90115 & Manual excavation in urbanized area $>2.50 \mathrm{~m}$ & $\mathrm{~m}^{3}$ & 7.568 & 32.83 & -0.0606 & 30.1147 & 906.4 \\
\hline 15MPP90125 & Mechanical excavation in urbanized area $>2.50 \mathrm{~m}$ & $\mathrm{~m}^{3}$ & 17.658 & 6.65 & -0.0125 & 6.6261 & 199.4 \\
\hline 15MTW00005 & $\begin{array}{c}\text { Internal transport of material from excavation. } \\
\text { Manual means }\end{array}$ & $\mathrm{m}^{3}$ & 7.568 & 5.86 & 0 & 0 & 0 \\
\hline 15MTW00010 & $\begin{array}{l}\text { Internal transport of material from excavation. } \\
\text { Mechanical means }\end{array}$ & $\mathrm{m}^{3}$ & 17.658 & 0.17 & 0.0004 & 0.0004 & 0 \\
\hline 15MMW90160 & Manhole-fill with sand. Mechanical means & $\mathrm{m}^{3}$ & 14.014 & 15.58 & 0.0165 & 0.3869 & 90.1 \\
\hline 15MGG00410 & Polyethylene geomembrane on sub-base foundation & $\mathrm{m}^{2}$ & 9.009 & 0.99 & 0.0005 & 0.0208 & 17.7 \\
\hline 03НММ00012 & Blinding concrete $\mathrm{HM}-20 / \mathrm{P} / 40 / \mathrm{I}$ & $\mathrm{m}^{3}$ & 1.802 & 70.55 & 0.2417 & 3.6014 & 1333.6 \\
\hline 03HAL00715 & Concrete HA-25/P/20/IIa in foundation & $\mathrm{m}^{3}$ & 1.952 & 74.7 & 0.2927 & 4.3723 & 1606.8 \\
\hline 03НАМ00750 & Concrete HA-25/B/20/IIa in walls & $\mathrm{m}^{3}$ & 2.342 & 73.3 & 0.2959 & 4.4155 & 1627.8 \\
\hline 03ACC00811 & B500S corrugated steel bars & $\mathrm{kg}$ & 328.236 & 1.49 & 0.0016 & 0.0295 & 25.5 \\
\hline 03ERM00011 & Wooden Formwork for Foundation & $\mathrm{m}^{2}$ & 4.004 & 9.76 & -0.0115 & 5.5177 & 166.1 \\
\hline 03ERT00011 & Metallic formwork for foundation & $\mathrm{m}^{2}$ & 15.616 & 26.31 & -0.0067 & 4.6274 & 183.2 \\
\hline 15URC00050 & Underground container, 4000 L & $\mathrm{u}$ & 1.001 & 3923.27 & 5.0822 & 104.7827 & $83,561.5$ \\
\hline 15UFF50010 & Drinking fountain & $\mathbf{u}$ & & 1032.95 & 0.0741 & 16.1298 & 2236 \\
\hline 15MZZ90110 & Manual trench excavation in urbanized area $<2.50 \mathrm{~m}$ & $\mathrm{~m}^{3}$ & 7.999 & 14.18 & -0.0235 & 12.0475 & 385 \\
\hline 15MTW00005 & $\begin{array}{l}\text { Internal transport of material from excavation. } \\
\text { Manual means }\end{array}$ & $\mathrm{m}^{3}$ & 7.999 & 5.86 & 0 & 0 & 0 \\
\hline 15MMG90210 & Trench-fill with granular material. Manual means & $\mathrm{m}^{3}$ & 2.75 & 16.61 & 0.0241 & 2.5613 & 330.4 \\
\hline 15MMW90160 & Manhole-fill with sand. Mechanical means & $\mathrm{m}^{3}$ & 5.199 & 15.58 & 0.0165 & 0.3869 & 90.1 \\
\hline 15SCE01020 & Polyethylene pipe PE100 diam. 40 mm PN-10 & $\mathrm{m}$ & 15.998 & 7.44 & 0.003 & 0.0467 & 53.2 \\
\hline 15SVE01020 & Manual ball valve diam. $40 \mathrm{~mm}$ PN-10 & $\mathrm{u}$ & 1 & 117.13 & 0.0084 & 0.1302 & 141.6 \\
\hline 15UPF00010 & Stainless steel drinking water fountain & $\mathrm{u}$ & 1 & 856.15 & 0.0456 & 0.9572 & 1235.7 \\
\hline 15UFF50011 & Street fountain & $\mathbf{u}$ & & 7337.6 & 1.9022 & 132.917 & $20,479.6$ \\
\hline 15MAA90010 & Excavation in urbanized area & $\mathrm{m}^{3}$ & 100.2 & 4.08 & 0.007 & 0.007 & 0 \\
\hline 15MTW00010 & $\begin{array}{c}\text { Internal transport of material from excavation. } \\
\text { Mechanical means }\end{array}$ & $\mathrm{m}^{3}$ & 100.2 & 0.17 & 0.0004 & 0.0004 & 0 \\
\hline 15MMW90160 & Manhole-fill with sand. Mechanical means & $\mathrm{m}^{3}$ & 46.2 & 15.58 & 0.0165 & 0.3869 & 90.1 \\
\hline 15MCC00101 & Superficial compaction with mechanical means & $\mathrm{m}^{3}$ & 63 & 2.08 & 0.0005 & 0.068 & 1.8 \\
\hline 15MMS00180 & Rampart with selected soil. Mechanical means & $\mathrm{m}^{3}$ & 18 & 4.8 & 0.0212 & 0.4119 & 49.8 \\
\hline 15MMG00110 & Artificial graded aggregate & $\mathrm{m}^{3}$ & 1.2 & 11.66 & 0.0249 & 2.4833 & 328.3 \\
\hline 03НMM00012 & Blinding concrete $\mathrm{HM}-20 / \mathrm{P} / 40 / \mathrm{I}$ & $\mathrm{m}^{3}$ & 0.6 & 70.55 & 0.2417 & 3.6014 & 1333.6 \\
\hline
\end{tabular}


Table A1. Cont.

\begin{tabular}{|c|c|c|c|c|c|c|c|}
\hline ACCD Code & Description & $\mathbf{U}$ & Quantity & Cost (EUR/U) & $\mathrm{CF}\left(\mathrm{tCO}_{2} \mathrm{eq} / \mathrm{U}\right)$ & $\mathrm{WF}\left(\mathrm{m}^{3}\right.$ water $\left./ \mathrm{U}\right)$ & $\mathrm{EE}(\mathrm{MJ} / \mathrm{U})$ \\
\hline 03HAL00715 & Concrete HA-25/P/20/IIa in foundation & $\mathrm{m}^{3}$ & 16.05 & 74.7 & 0.2927 & 4.3723 & 1606.8 \\
\hline 03НАМ00750 & Concrete HA-25/B/20/IIa in walls & $\mathrm{m}^{3}$ & 21.825 & 73.3 & 0.2959 & 4.4155 & 1627.8 \\
\hline 03HAL00765 & Concrete HA-25/B/20/IIa in slabs & $\mathrm{u}$ & 1.5 & 77.74 & 0.2961 & 4.4173 & 1631.7 \\
\hline 03АСC00811 & B500S corrugated steel bars & $\mathrm{m}^{2}$ & 3396.412 & 1.49 & 0.0016 & 0.0295 & 25.5 \\
\hline 03ERM00011 & Wooden formwork for foundation & $\mathrm{m}^{2}$ & 36 & 9.76 & -0.0115 & 5.5177 & 166.1 \\
\hline 03ERT00011 & Metallic formwork for foundation & $m^{2}$ & 181.8 & 26.31 & -0.0067 & 4.6274 & 183.2 \\
\hline 15ASW00100 & Polyethylene manhole step & $\mathrm{u}$ & 10 & 19.16 & 0.0067 & 0.1877 & 208.2 \\
\hline 10ACN00111 & Grey granite, polished, $2 \mathrm{~cm}$ & $\mathrm{~m}^{2}$ & 68.75 & 121.73 & 0.0507 & 29.7471 & 912 \\
\hline 10ACN00112 & Black granite, polished, $2 \mathrm{~cm}$ & $\mathrm{~m}^{2}$ & 67.6 & 219 & 0.0507 & 29.7471 & 912 \\
\hline 10SES00150 & Surface water proofing treatment & $\mathrm{m}^{2}$ & 98.75 & 12.73 & 0.0034 & 0.0754 & 300 \\
\hline 10ACW00112 & Black granite polished piece, $60 \times 40 \mathrm{~cm}$ max. & $\mathrm{u}$ & 1 & 219 & 0.0507 & 29.7471 & 912 \\
\hline 15ADW00110 & Filling and depuration compact system for street fountain & $\mathrm{u}$ & 1 & 5279.13 & 0.3412 & 8.0906 & 6272.3 \\
\hline 15UPW00120 & Compact recirculation system for fountain & $\mathrm{m}$ & 1 & 1094.63 & 0.2185 & 4.9834 & 3918.4 \\
\hline 15ACV50140 & Trench to draining pipe DN 200 up to $3 \mathrm{~m}$ deep & m & & 4091.87 & 4.5653 & 402.8376 & $66,946.9$ \\
\hline $15 \mathrm{MZZ90110}$ & Manual trench excavation in urbanized area $<2.50 \mathrm{~m}$ & $\mathrm{~m}^{3}$ & 0.488 & 14.18 & -0.0235 & 12.0475 & 385 \\
\hline $15 \mathrm{MZZ} 90120$ & Mechanical trench excavation in urbanized area $<2.50 \mathrm{~m}$ & $\mathrm{~m}^{3}$ & 1.138 & 3.01 & -0.0056 & 3.0119 & 100.6 \\
\hline 15MTW00005 & $\begin{array}{c}\text { Internal transport of material from excavation. Manual } \\
\text { means }\end{array}$ & $\mathrm{m}^{3}$ & 0.488 & 5.86 & 0 & 0 & 0 \\
\hline 15MTW00010 & $\begin{array}{c}\text { Internal transport of material from excavation. Mechanical } \\
\text { means }\end{array}$ & $\mathrm{m}^{3}$ & 1.138 & 0.17 & 0.0004 & 0.0004 & 0 \\
\hline 15MGG00170 & Geotextile sheet $125-160 \mathrm{gr} / \mathrm{m}^{2}$ & $\mathrm{~m}^{2}$ & 7.202 & 2.1 & 0.0003 & 0.0107 & 9 \\
\hline 15MGD00140 & PVC drainage pipe, diam. $200 \mathrm{~mm}$ & $\mathrm{~m}$ & 1 & 12.79 & 0.0443 & 6.4776 & 1145.5 \\
\hline 15MGG00810 & HD polyethylene geomembrane, $1.5 \mathrm{~mm}$ & $\mathrm{~m}^{2}$ & 4.001 & 4.36 & 0.0043 & 0.1798 & 152.9 \\
\hline 15MMG00250 & Trench-fill with draining material. Mechanical means & $\mathrm{m}^{3}$ & 0.25 & 12.23 & 0.023 & 2.3695 & 292.5 \\
\hline 15MMG00350 & Trench-fill with filter material. Mechanical means & $\mathrm{m}^{3}$ & 1.375 & 11.85 & 0.0194 & 2.3695 & 155.1 \\
\hline 15ADD00100 & Concrete drainage manhole $1.00 \times 1.00 \mathrm{~m}$, depth $>2.50 \mathrm{~m}$ & u & 0.015 & 2265.75 & 1.8324 & 199.7122 & 25972.3 \\
\hline 15ADD00110 & Storm overflow manhole $1.00 \times 1.00 \mathrm{~m}$, depth $>2.00 \mathrm{~m}$ & $\mathrm{u}$ & 0.015 & 1759.57 & 2.6703 & 176.6585 & 38734 \\
\hline
\end{tabular}


Table A1. Cont.

\begin{tabular}{|c|c|c|c|c|c|c|c|}
\hline ACCD Code & Description & $\mathbf{U}$ & Quantity & Cost (EUR/U) & $\mathrm{CF}\left(\mathrm{tCO}_{2} \mathrm{eq} / \mathrm{U}\right)$ & $\mathrm{WF}\left(\mathrm{m}^{3}{ }_{\text {water }} / \mathrm{U}\right)$ & $\mathrm{EE}(\mathrm{MJ} / \mathrm{U})$ \\
\hline $15 C S S 50120$ & Transfer traffic light, $6 \mathrm{~m}$ high & $\mathbf{u}$ & & 1600.28 & 1.2664 & 15.058 & 9062.2 \\
\hline 15CSE03160 & 2 PVC pipes, diam. $110 \mathrm{~mm}$, for traffic light network & $\mathrm{m}$ & 20 & 25.44 & 0.0247 & 2.426 & 315.2 \\
\hline 15CSR00100 & Highway manhole, $60 \times 60 \mathrm{~cm}$ & $\mathrm{u}$ & 1 & 157.04 & 0.1978 & 2.35 & 2300.9 \\
\hline 03НММ00035 & Earthing rods in traffic light & $\mathrm{u}$ & 1 & 87.25 & 0.202 & 2.7037 & 1384.8 \\
\hline 15CSW00120 & Earthing rods in traffic light & $\mathrm{u}$ & 1 & 61.28 & 0.0091 & 0.3647 & 163.1 \\
\hline 15RCW00120 & Displacement of 6-m-high traffic light & $\mathrm{u}$ & 1 & 563.99 & 0.5984 & 1.9326 & 807 \\
\hline $15 \mathrm{CSCE} 02270$ & Copper circuit, $1 \times 16 \mathrm{~mm}^{2} \mathrm{HO}-\mathrm{K}(\mathrm{AS})$ & $\mathrm{m}$ & 20 & 16.87 & 0.0003 & 0.0115 & 5.5 \\
\hline 15RCW00500 & Connection closet & $\mathrm{u}$ & 1 & 205.74 & 0.2057 & 4.3462 & 3512.2 \\
\hline 15RCW00600 & Electronic regulator transfer & $\mathrm{u}$ & 1 & 367.65 & 0.0021 & 0.0071 & 4.2 \\
\hline 15CSW02010 & Connection cabinet—-traffic light regulator & $\mathrm{m}$ & 20 & 115.02 & 0.0263 & 0.9162 & 569.3 \\
\hline 15PPP50180 & Cycle paths & $\mathrm{m}^{2}$ & & 83.56 & 0.2579 & 6.1197 & 1827.9 \\
\hline 15MAA90010 & Excavation in urbanized area & $\mathrm{m}^{3}$ & 0.58 & 4.08 & 0.007 & 0.007 & 0 \\
\hline 15MTW00010 & $\begin{array}{c}\text { Internal transport of material from excavation. } \\
\text { Mechanical means }\end{array}$ & $\mathrm{m}^{3}$ & 0.58 & 0.17 & 0.0004 & 0.0004 & 0 \\
\hline 15MCC00101 & Superficial compaction with mechanical means & $\mathrm{m}^{2}$ & 1 & 2.08 & 0.0005 & 0.068 & 1.8 \\
\hline 15MMS00180 & Rampart with selected soil. Mechanical means & $\mathrm{m}^{3}$ & 0.3 & 4.8 & 0.0212 & 0.4119 & 49.8 \\
\hline 15MMG00110 & Artificial graded aggregate & $\mathrm{m}^{3}$ & 0.2 & 11.66 & 0.0249 & 2.4833 & 328.3 \\
\hline 15РBB01010 & $\begin{array}{l}\text { Prefabricated curb of photocatalytic concrete (R5) DE } \\
\qquad 30 / 40 \times 70 \mathrm{~cm}\end{array}$ & $\mathrm{~m}$ & 0.4 & 60.03 & 0.2035 & 3.1393 & 1437.9 \\
\hline 15СРР00100 & Road markings, $10 \mathrm{~cm}$ wide & $\mathrm{m}$ & 1.2 & 0.74 & 0.0004 & 0.0098 & 10.1 \\
\hline 15PРP50111 & Bituminous Concrete Driveway & $\mathrm{m}^{2}$ & & 214.17 & 0.4301 & 18.6928 & 6497.1 \\
\hline 15MAA90010 & Excavation in urbanized area & $\mathrm{m}^{3}$ & 0.58 & 4.08 & 0.007 & 0.007 & 0 \\
\hline 15MTW00010 & $\begin{array}{c}\text { Internal transport of material from excavation. } \\
\text { Mechanical means }\end{array}$ & $\mathrm{m}^{3}$ & 0.58 & 0.17 & 0.0004 & 0.0004 & 0 \\
\hline 15MCC00101 & Superficial compaction with mechanical means & $\mathrm{m}^{2}$ & 1 & 2.08 & 0.0005 & 0.068 & 1.8 \\
\hline 15MMS00180 & Rampart with selected soil. Mechanical means & $\mathrm{m}^{3}$ & 0.5 & 4.8 & 0.0212 & 0.4119 & 49.8 \\
\hline 15MMG00110 & Artificial graded aggregate & $\mathrm{m}^{3}$ & 0.25 & 11.66 & 0.0249 & 2.4833 & 328.3 \\
\hline 15 PCC00110 & Asphalt concrete AC 32 BASE B 50/70 G & $\mathrm{m}^{3}$ & 0.07 & 128.55 & 0.2329 & 9.0222 & 3917 \\
\hline 15 PCC00120 & Asphalt concrete AC 22 BIN B 50/70 S & $\mathrm{m}^{3}$ & 0.06 & 62.83 & 0.1432 & 6.7 & 2200.2 \\
\hline
\end{tabular}


Table A1. Cont.

\begin{tabular}{|c|c|c|c|c|c|c|c|}
\hline ACCD Code & Description & $\mathbf{U}$ & Quantity & Cost (EUR/U) & $\mathrm{CF}\left(\mathrm{tCO}_{2} \mathrm{eq} / \mathrm{U}\right)$ & $\mathrm{WF}\left(\mathrm{m}^{3}\right.$ water $\left./ \mathrm{U}\right)$ & $\mathrm{EE}(\mathrm{MJ} / \mathrm{U})$ \\
\hline 15PPP50250 & $\begin{array}{l}\text { Pavement in children's play area with artificial grass and } \\
\text { absorbent base }\end{array}$ & $\mathbf{m}^{2}$ & & 43.76 & 0.0297 & 1.5829 & 371.9 \\
\hline 15MAA90010 & Excavation in urbanized area & $\mathrm{m}^{3}$ & 0.4 & 4.08 & 0.007 & 0.007 & 0 \\
\hline 15MTW00010 & $\begin{array}{c}\text { Internal transport of material from excavation. Mechanical } \\
\text { means }\end{array}$ & $\mathrm{m}^{3}$ & 0.4 & 0.17 & 0.0004 & 0.0004 & 0 \\
\hline 15MCC00101 & Superficial compaction with mechanical means & $\mathrm{m}^{2}$ & 1 & 2.08 & 0.0005 & 0.068 & 1.8 \\
\hline 15РPР01250 & $\begin{array}{c}\text { Pavement in children's play area of artificial grass and } \\
\text { shock absorbent base }\end{array}$ & $\mathrm{m}^{2}$ & 1 & 37.43 & 0.0218 & 1.5075 & 370.1 \\
\hline 15PPP50120 & Pavement in parking area with paving blocks & $\mathrm{m}^{2}$ & & 58.11 & 0.0923 & 1.4761 & 521.4 \\
\hline 15MAA90010 & Excavation in urbanized area & $\mathrm{m}^{3}$ & 0.8 & 4.08 & 0.007 & 0.007 & 0 \\
\hline 15MTW00010 & $\begin{array}{c}\text { Internal transport of material from excavation. Mechanical } \\
\text { means }\end{array}$ & $\mathrm{m}^{3}$ & 0.8 & 0.17 & 0.0004 & 0.0004 & 0 \\
\hline 15MCC00101 & Superficial compaction with mechanical means & $\mathrm{m}^{2}$ & 1 & 2.08 & 0.0005 & 0.068 & 1.8 \\
\hline 15MMS00180 & Rampart with selected soil. Mechanical means & $\mathrm{m}^{3}$ & 0.4 & 4.8 & 0.0212 & 0.4119 & 49.8 \\
\hline 15РРР01120 & $\begin{array}{l}\text { Interlocking concrete block pavement, } 30 \times 20 \times 10 \mathrm{~cm} \text {, } \\
\text { photocatalytic }\end{array}$ & $\mathrm{m}^{2}$ & 1 & 46.98 & 0.0632 & 0.9888 & 469.8 \\
\hline 15PPP50110 & Sidewalk with concrete paving blocks & $\mathrm{m}^{2}$ & & 37.19 & 0.0994 & 1.5906 & 506.3 \\
\hline 15MAA90010 & Excavation in urbanized area & $\mathrm{m}^{3}$ & 0.55 & 4.08 & 0.007 & 0.007 & 0 \\
\hline 15MTW00010 & $\begin{array}{c}\text { Internal transport of material from excavation. Mechanical } \\
\text { means }\end{array}$ & $\mathrm{m}^{3}$ & 0.55 & 0.17 & 0.0004 & 0.0004 & 0 \\
\hline 15MCC00101 & Superficial compaction with mechanical means & $\mathrm{m}^{2}$ & 1 & 2.08 & 0.0005 & 0.068 & 1.8 \\
\hline 15MMS00180 & Rampart with selected soil. Mechanical means & $\mathrm{m}^{3}$ & 0.3 & 4.8 & 0.0212 & 0.4119 & 49.8 \\
\hline 15PSS00150 & Concrete slab HM-20 DE $15 \mathrm{~cm}$ & $\mathrm{~m}^{2}$ & 1 & 10.37 & 0.0361 & 0.5385 & 197.9 \\
\hline 15РРР01110 & $\begin{array}{l}\text { Smooth concrete block pavement } 40 \times 20 \times 6 \mathrm{~cm} \text {, } \\
\text { photocatalytic }\end{array}$ & $\mathrm{m}^{2}$ & 1 & 15.69 & 0.0342 & 0.5648 & 256.8 \\
\hline 15EPP00105 & Galvanized steel streetlight 6 m LEDS light & $\mathbf{u}$ & 1 & 1023.07 & 3.425 & 70.992 & $56,601.6$ \\
\hline 15UPA0010 & Bench with metallic support and Nordic pine seat & $\mathbf{u}$ & 1 & 256.29 & -0.041 & 0.227 & 655.7 \\
\hline 15URP00010 & Metallic waste bin & $\mathbf{u}$ & 1 & 457.78 & 0.271 & 4.348 & 1979.1 \\
\hline 15UPA0005 & White concrete bench & $\mathbf{u}$ & 1 & 940.84 & 2.052 & 28.071 & $13,531.7$ \\
\hline 15UPB00100 & Children's seewaw & $\mathbf{u}$ & 1 & 1005.29 & 0.396 & 7.351 & 4847.6 \\
\hline 15CRR10102 & Vertical traffic sign & $\mathbf{u}$ & 1 & 114.12 & 0.31 & 6.141 & 4513 \\
\hline
\end{tabular}




\section{References}

1. European Parliament-Council of the European Union. Directive EU 2018/844 of the European Parliament and of the Council of 30 May 2018 amending Directive 2010/31/EU on the energy performance of buildings and Directive 2012/27/EU on energy efficiency (Text with EEA relevance). Off. J. Eur. Union 2018, 61, 75.

2. Cabeza, L.F.; Rincón, L.; Vilariño, V.; Pérez, G.; Castell, A. Life cycle assessment (LCA) and life cycle energy analysis (LCEA) of buildings and the building sector: A review. Renew. Sustain. Energy Rev. 2014, 29, $394-416$. [CrossRef]

3. Pulselli, R.M.; Simoncini, E.; Pulselli, F.M.; Bastianoni, S. Emergy analysis of building manufacturing, maintenance and use: Em-building indices to evaluate housing sustainability. Energy Build. 2007, 39, 620-628. [CrossRef]

4. Pulselli, R.M.; Pulselli, F.M.; Mazzali, U.; Peron, F.; Bastianoni, S. Emergy based evaluation of environmental performances of Living Wall and Grass Wall systems. Energy Build. 2014, 73, 200-211. [CrossRef]

5. Solís-Guzmán, J.; Marrero, M.; Ramírez-de-Arellano, A. Methodology for determining the ecological footprint of the construction of residential buildings in Andalusia (Spain). Ecol. Indic. 2013, 25, 239-249. [CrossRef]

6. Martínez-Rocamora, A.; Solís-Guzmán, J.; Marrero, M. Toward the Ecological Footprint of the use and maintenance phase of buildings: Utility consumption and cleaning tasks. Ecol. Indic. 2016, 69, 66-77. [CrossRef]

7. Martínez-Rocamora, A.; Solís-Guzmán, J.; Marrero, M. Ecological footprint of the use and maintenance phase of buildings: Maintenance tasks and final results. Energy Build. 2017, 155, 339-351. [CrossRef]

8. Marrero, M.; Rivero-Camacho, C.; Alba-Rodríguez, M.D. What are we discarding during the life cycle of a building? Case studies of social housing in Andalusia, Spain. Waste Manag. 2020, 102, 391-403. [CrossRef]

9. Freire-Guerrero, A.; Alba-Rodríguez, M.D.; Marrero, M. A budget for the ecological footprint of buildings is possible: A case study using the dwelling construction cost database of Andalusia. Sustain. Cities Soc. 2019, 51, 101737. [CrossRef]

10. UNE-EN 15978. Sustainability of Construction Works. Assessment of Environmental Performance of Buildings. Calculation Method; AENOR: Madrid, Spain, 2012.

11. Knutt, E. Spain Launches BIM Strategy with Pencilled-in 2018 Mandate. Available online: http://www. bimplus.co.uk/news/spain-launches-bim-strategy-pencilled-2018-mandate/ (accessed on 1 May 2020).

12. AEC (UK) Committee. AEC (UK) BIM Technology Protocol, Practical Implementation of BIM for the UK Architectural, Engineering and Construction (AEC) Industry; AEC Initiative: London, UK, 2015.

13. BMVI. BIM in Europe: Germany's Public Plan for 2015/2020 and Pilot Projects for Roads and Railways-BibLus; Germany's Federal Ministry of Transport and Digital Infrastructure (BMVI): Berlin, Germany, 2013.

14. Delcambre, B. Mission Numérique Bâtiment Rapport; French Government: Paris, France, 2014.

15. Bey, N.; Hauschild, M.Z.; McAloone, T.C. Drivers and barriers for implementation of environmental strategies in manufacturing companies. CIRP Ann. 2013, 62, 43-46. [CrossRef]

16. Mousa, M.; Luo, X.; McCabe, B. Utilizing BIM and Carbon Estimating Methods for Meaningful Data Representation. Procedia Eng. 2016, 145, 1242-1249. [CrossRef]

17. Cheung, F.K.T.; Rihan, J.; Tah, J.; Duce, D.; Kurul, E. Early stage multi-level cost estimation for schematic BIM models. Autom. Constr. 2012, 27, 67-77. [CrossRef]

18. Wong, J.K.W.; Zhou, J. Enhancing environmental sustainability over building life cycles through green BIM: A review. Autom. Constr. 2015, 57, 156-165. [CrossRef]

19. Soust-Verdaguer, B.; Llatas, C.; García-Martínez, A. Critical review of bim-based LCA method to buildings. Energy Build. 2017, 136, 110-120. [CrossRef]

20. Eleftheriadis, S.; Mumovic, D.; Greening, P. Life cycle energy efficiency in building structures: A review of current developments and future outlooks based on BIM capabilities. Renew. Sustain. Energy Rev. 2017, 67, 811-825. [CrossRef]

21. Kulahcioglu, T.; Dang, J.; Toklu, C. A 3D analyzer for BIM-enabled Life Cycle Assessment of the whole process of construction. HVAC R Res. 2012, 18, 283-293.

22. Lamé, G.; Leroy, Y.; Yannou, B. Ecodesign tools in the construction sector: Analyzing usage inadequacies with designers' needs. J. Clean. Prod. 2017, 148, 60-72. [CrossRef]

23. Chong, H.Y.; Lee, C.Y.; Wang, X. A mixed review of the adoption of Building Information Modelling (BIM) for sustainability. J. Clean. Prod. 2017, 142, 4114-4126. [CrossRef] 
24. Ilhan, B.; Yaman, H. Green building assessment tool (GBAT) for integrated BIM-based design decisions. Autom. Constr. 2016, 70, 26-37. [CrossRef]

25. Fiès, B.; Lützkendorf, T.; Balouktsi, M. Life Cycle Sustainable Assessment and BIM. In Sustainable Buildings Construction Products and Technologies; University of Technology: Graz, Austria, 2013.

26. Santos, R.; Costa, A.A.; Silvestre, J.D.; Pyl, L. Integration of LCA and LCC analysis within a BIM-based environment. Autom. Constr. 2019, 103, 127-149. [CrossRef]

27. Bovea, M.D.; Powell, J.C. Developments in life cycle assessment applied to evaluate the environmental performance of construction and demolition wastes. Waste Manag. 2016, 50, 151-172. [CrossRef] [PubMed]

28. International Organization for Standardization. ISO 14040:2006: Environmental Management-Life Cycle Assessment_-Principles and Framework; ISO: Geneva, Switzerland, 2006.

29. International Organization for Standardization. ISO 14044:2006: Environmental Management-Life Cycle Assessment-Requirements and Guidelines; ISO: Geneva, Switzerland, 2006.

30. European Commission. Buying Green! A Handbook on Green Public Procurement; European Union: Brussels, Belgium, 2016.

31. Bueno, C.; Fabricio, M.M. Comparative analysis between a complete LCA study and results from a BIM-LCA plug-in. Autom. Constr. 2018, 90, 188-200. [CrossRef]

32. Stadel, A.; Eboli, J.; Ryberg, A.; Mitchell, J.; Spatari, S. Intelligent Sustainable Design: Integration of Carbon Accounting and Building Information Modeling. J. Prof. Issues Eng. Educ. Pract. 2011, 137, 51-54. [CrossRef]

33. Cavalliere, C.; Dell'Osso, G.R.; Pierucci, A.; Iannone, F. Life cycle assessment data structure for building information modelling. J. Clean. Prod. 2018, 199, 193-204. [CrossRef]

34. UNE-EN ISO 14024. Environmental Labels and Declarations-Type I Environmental Labelling-Principles and Procedures; AENOR: Madrid, Spain, 2001.

35. UNE-EN ISO 14021. Environmental Labels and Declarations-Self-Declared Environmental Claims (Type II Environmental Labelling); AENOR: Madrid, Spain, 2017.

36. UNE-EN ISO 14025. Environmental Labels and Declarations_Type III Environmental Declarations_Principles and Procedures; AENOR: Madrid, Spain, 2006.

37. UNE-EN 15804. Sustainability of Construction Works-Environmental Product Declarations-Core Rules for the Product Category of Construction Products; AENOR: Madrid, Spain, 2012.

38. Pasanen, P.; Sipari, A.; Terranova, E.; Castro, R.; Bruce-Hyrkas, T. The Embodied Carbon Review-Embodied Carbon Reduction 100+ Regulations and Rating Systems Globally; Bionova Ltd.: Helsinki, Finland, 2018.

39. European Commission. Single Market for Green Products; European Commission; European Union: Brussels, Belgium, 2016.

40. European Parliament. Resolution of 9 July 2015 on Resource Efficiency: Moving Towards a Circular Economy (2014/2208(INI)); European Union: Brussels, Belgium, 2015.

41. EPD System. International EPD ${ }^{\circledR}$ System. Available online: https://www.environdec.com/es/ (accessed on 20 February 2020).

42. European Commission. Single Market for Green Products-The Product Environmental Footprint Pilots_Environment_European Commission; European Union: Brussels, Belgium, 2019.

43. FVS. Sello de Huella Ambiental FVS|Fundación Vida Sostenible. Available online: https://www.vidasostenible. org/sello-de-huella-ambiental-fvs/ (accessed on 20 February 2020).

44. ECoPlatform. Available online: https://www.eco-platform.org/ (accessed on 20 February 2020).

45. European Commission. Sustainable Buildings_Green Growth and Circular Economy_Environment-European Commission; European Union: Brussels, Belgium, 2019.

46. Almeida, C.P.; Ramos, A.F.; Silva, J.M. Sustainability assessment of building rehabilitation actions in old urban centres. Sustain. Cities Soc. 2018, 36, 378-385. [CrossRef]

47. Sinha, R.; Lennartsson, M.; Frostell, B. Environmental footprint assessment of building structures: A comparative study. Build. Environ. 2016, 104, 162-171. [CrossRef]

48. Marrero, M.; Ramirez-de-Arellano, A. The building cost system in Andalusia: Application to construction and demolition waste management. Constr. Manag. Econ. 2010, 28, 495-507. [CrossRef]

49. Guerrero, A.F.; Marrero, M. Evaluation of the embodied energy of a construction project using the budget. Habitat Sustentable 2015, 5, 54-63. 
50. Guerrero, A.F.; Meléndez, M.M.; Martín, J.M. Incorporación de huella de carbono y huella ecológica en las bases de costes de construcción. Estudio de caso de un proyecto de urbanización en Écija, España. Hábitat Sustentable 2016, 6, 6-17. [CrossRef]

51. Solís-Guzmán, J.; Martínez-Rocamora, A.; Marrero, M. Methodology for determining the carbon footprint of the construction of residential buildings. In Assessment of Carbon Footprint in Different Industrial Sectors; Springer: Singapore, 2014; pp. 49-83.

52. Solís-Guzmán, J.; Rivero-Camacho, C.; Alba-Rodríguez, D.; Martínez-Rocamora, A. Carbon Footprint Estimation Tool for Residential Buildings for Non-Specialized Users: OERCO2 Project. Sustainability 2018, 10, 1359. [CrossRef]

53. Ruiz-Pérez, M.R.; Rodríguez, M.D.A.; Marrero, M. Systems of Water Supply and Sanitation for Domestic Use. In Water Footprint and Carbon Footprint Evaluation: First Results; IV International Congress on Construction and Building Research-Santa Cruz de Tenerife: Tenerife, Spain, 2017.

54. Ruiz-Pérez, M.R.; Alba-Rodríguez, M.D.; Marrero, M. The water footprint of city naturalisation. Evaluation of the water balance of city gardens. Ecological Modelling. 2020, 424, 109031. [CrossRef]

55. Ruiz-Pérez, M.R.; Alba-Rodríguez, M.D.; Castaño-Rosa, R.; Solís-Guzmán, J.; Marrero, M. HEREVEA Tool for Economic and Environmental Impact Evaluation for Sustainable Planning Policy in Housing Renovation. Sustainability 2019, 11, 2852. [CrossRef]

56. Marrero, M.; Martin, C.; Muntean, R.; González-Vallejo, P.; Rodríguez-Alba, M.D. Tools to quantify environmental impact and their application to teaching: Projects City-zen and HEREVEA. IOP Conf. Ser. Mater. Sci. Eng. 2018, 399, 012038. [CrossRef]

57. Solís-Guzmán, J.; Rivero-Camacho, C.; Tristancho, M.; Martínez-Rocamora, A.; Marrero, M. Software for Calculation of Carbon Footprint for Residential Buildings. In Environmental Footprints and Eco-Design of Products and Processes; Springer: Basel, Switzerland, 2020; pp. 55-79.

58. Basbagill, J.; Flager, F.; Lepech, M.; Fischer, M. Application of life-cycle assessment to early stage building design for reduced embodied environmental impacts. Build. Environ. 2013, 60, 81-92. [CrossRef]

59. Kreiner, H.; Passer, A.; Wallbaum, H. A new systemic approach to improve the sustainability performance of office buildings in the early design stage. Energy Build. 2015, 109, 385-396. [CrossRef]

60. Jalaei, F; Jrade, A. Integrating Building Information Modeling (BIM) and energy analysis tools with green building certification system to conceptually design sustainable buildings. J. Inf. Technol. Constr. 2014, 19, 494-519.

61. Marzouk, M.; Abdelkader, E.M.; Al-Gahtani, K. Building information modeling-based model for calculating direct and indirect emissions in construction projects. J. Clean. Prod. 2017, 152, 351-363. [CrossRef]

62. Chen, L.; Pan, W. A BIM-integrated Fuzzy Multi-criteria Decision Making Model for Selecting Low-Carbon Building Measures. Procedia Eng. 2015, 118, 606-613. [CrossRef]

63. Gul, M.; Celik, E.; Gumus, A.T.; Guneri, A.F. A fuzzy logic based PROMETHEE method for material selection problems. Beni-Suef Univ. J. Basic Appl. Sci. 2018, 7, 68-79. [CrossRef]

64. Ajayi, S.O.; Oyedele, L.O.; Ceranic, B.; Gallanagh, M.; Kadiri, K.O. Life cycle environmental performance of material specification: A BIM-enhanced comparative assessment. Int. J. Sustain. Build. Technol. Urban Dev. 2015, 6, 14-24. [CrossRef]

65. Crippa, J.; Boeing, L.C.; Caparelli, A.P.A.; de Mello Maron, M.D.R.; Scheer, S.; Araujo, A.M.F.; Bem, D. A BIM-LCA integration technique to embodied carbon estimation applied on wall systems in Brazil. Built Environ. Proj. Asset Manag. 2018, 8, 491-503. [CrossRef]

66. Najjar, M.; Figueiredo, K.; Palumbo, M.; Haddad, A. Integration of BIM and LCA: Evaluating the environmental impacts of building materials at an early stage of designing a typical office building. J. Build. Eng. 2017, 14, 115-126. [CrossRef]

67. Schultz, J.; Ku, K.; Gindlesparger, M.; Doerfler, J. A benchmark study of BIM-based whole-building life-cycle assessment tools and processes. Int. J. Sustain. Build. Technol. Urban Dev. 2016, 7, 219-229. [CrossRef]

68. Azhar, S.; Carlton, W.A.; Olsen, D.; Ahmad, I. Building information modeling for sustainable design and LEED $^{\circledR}$ rating analysis. Autom. Constr. 2011, 20, 217-224. [CrossRef]

69. Antón, L.Á.; Díaz, J. Integration of life cycle assessment in a BIM environment. Procedia Eng. 2014, 85, 26-32. [CrossRef]

70. Inyim, P.; Rivera, J.; Zhu, Y. Integration of building information modeling and economic and environmental impact analysis to support sustainable building design. J. Manag. Eng. 2014, 31, A4014002. [CrossRef] 
71. Gan, V.J.L.; Deng, M.; Tse, K.T.; Chan, C.M.; Lo, I.M.C.; Cheng, J.C.P. Holistic BIM framework for sustainable low carbon design of high-rise buildings. J. Clean. Prod. 2018, 195, 1091-1104. [CrossRef]

72. Gan, V.J.L.; Cheng, J.C.P.; Lo, I.M.C.; Chan, C.M. Developing a $\mathrm{CO}_{2}$-e accounting method for quantification and analysis of embodied carbon in high-rise buildings. J. Clean. Prod. 2017, 141, 825-836. [CrossRef]

73. Yang, X.; Hu, M.; Wu, J.; Zhao, B. Building-information-modeling enabled life cycle assessment, a case study on carbon footprint accounting for a residential building in China. J. Clean. Prod. 2018, 183, 729-743. [CrossRef]

74. Martínez-Rocamora, A.; Solís-Guzmán, J.; Marrero, M. LCA databases focused on construction materials: A review. Renew. Sustain. Energy Rev. 2016, 58, 565-573. [CrossRef]

75. Telford, T. Civil Engineering Standard Method of Measurement, 3rd ed.; Thomas Telford Ltd.: London, UK, 1991; pp. 4-39.

76. UniFormatTM. The Construction Specifications Institute: UniFormatTM: A Uniform Classification of Construction Systems and Assemblies; Construction Specifications Institute: Alexandria, VA, USA, 1998.

77. Omniclass. Omniclass: A Strategy for Classifying the Built Environment-Table 13: Spaces by Function; Construction Specifications Institute: Alexandria, VA, USA, 2012.

78. ISO 12006-2. Building Construction-Organization of Information about Construction Works—Part 2: Framework for Classification; ISO: Geneva, Switzerland, 2015.

79. CSI/CSC. Construction Specifications Institute/Construction Specifications Canada; MasterFormat 2016 Edition: Numbers and Titles; Construction Specifications Institute: Alexandria, VA, USA, 2016.

80. ITeC. BEDEC Website. ITecC. Barcelona. Available online: https://itec.es/ (accessed on 20 February 2020).

81. Ecoinvent Centre. Ecoinvent Database v3 Ecoinvent Report; Ecoinvent: Zurich, Switzerland, 2013.

82. PRé Sustainability. SimaPro 8. Available online: https://simapro.com/ (accessed on 28 March 2018).

83. SOFIAS Project. SOFIAS Project Website. 2017. Available online: http://161.111.70.91/index.php/es/actualidad/ actividades-y-cursos/conferencias-y-actos-publicos/243-finalsofias (accessed on 20 February 2020).

84. e2CO2cero. e2CO2cero Tool Website. 2014. Available online: http://online.e2co2cero.com/ (accessed on 20 February 2020).

85. Lützkendorf, T.; Foliente, G.; Balouktsi, M.; Wiberg, A.H. Net-zero buildings: Incorporating embodied impacts. Build. Res. Inf. 2015, 43, 62-81. [CrossRef]

86. Abanda, F.H.; Oti, A.H.; Tah, J.H.M. Integrating BIM and new rules of measurement for embodied energy and $\mathrm{CO}_{2}$ assessment. J. Build. Eng. 2017, 12, 288-305. [CrossRef]

87. Royal Institution of Chartered Surveyors. RICS NRM: New Rules of Measurement; RICS: London, UK, 2014.

88. Bath Inventory of Carbon and Energy (Bath ICE). Available online: https://circularecology.com/embodiedcarbon-footprint-database.html (accessed on 20 February 2020).

89. Mercader Moyano, M.D.P.; Camporeale, P.E.; Cózar-Cózar, E. Evaluación de impacto ambiental mediante la introducción de indicadores a un modelo BIM de vivienda social. Rev. Hábitat Sustentable 2019, 9, 78-93. [CrossRef]

90. Geng, S.; Wang, Y.; Zuo, J.; Zhou, Z.; Du, H.; Mao, G. Building life cycle assessment research: A review by bibliometric analysis. Renew. Sustain. Energy Rev. 2017, 76, 176-184. [CrossRef]

91. Dossche, C.; Boel, V.; de Corte, W. Use of Life Cycle Assessments in the Construction Sector: Critical Review. Procedia Eng. 2017, 171, 302-311. [CrossRef]

92. Chastas, P.; Theodosiou, T.; Kontoleon, K.J.; Bikas, D. Normalising and assessing carbon emissions in the building sector: A review on the embodied $\mathrm{CO}_{2}$ emissions of residential buildings. Build. Environ. 2018, 130, 212-226. [CrossRef]

93. Hoekstra, A.Y.; Chapagain, A.K.; Aldaya, M.M.; Mekonnen, M.M. Water Footprint Manual: State of the Art 2009; Water Footprint Network: Enschede, The Netherlands, 2009.

94. Hoekstra, A.Y.; Chapagain, A.K.; Aldaya, M.M.; Mekonnen, M.M. The Water Footprint Assessment Manual; Earthscan: London, UK, 2011.

95. WFN. Waterfootprint Network. Available online: https://waterfootprint.org/en/ (accessed on 20 February 2020).

96. Andalusia Government. Andalusia Construction Cost Database (ACCD); Andalusia Government: Andalusia, Spain, 2017.

97. Marrero, M.; Puerto, M.; Rivero-Camacho, C.; Freire-Guerrero, A.; Solís-Guzmán, J. Assessing the economic impact and ecological footprint of construction and demolition waste during the urbanization of rural land. Resour. Conserv. Recycl. 2017, 117, 160-174. [CrossRef] 
98. SEOPAN. Machinery Costs Manual (In Spanish: Manual de Costes de Maquinaria). 2008. Available online: http://www.concretonline.com/pdf/07construcciones/art_tec/SeopanManualCostes.pdf (accessed on 1 July 2016).

99. Röck, M.; Hollberg, A.; Habert, G.; Passer, A. LCA and BIM: Visualization of environmental potentials in building construction at early design stages. Build. Environ. 2018, 140, 153-161. [CrossRef]

(C) 2020 by the authors. Licensee MDPI, Basel, Switzerland. This article is an open access article distributed under the terms and conditions of the Creative Commons Attribution (CC BY) license (http://creativecommons.org/licenses/by/4.0/). 